This is the peer reviewed version of the following article:

Nikolić, Maria Vesna, Zorka Ž. Vasiljević, Miloljub D. Luković, Vera P. Pavlović, Jugoslav B. Krstić, Jelena Vujančević, Nenad Tadić, Branislav Vlahović, and Vladimir B. Pavlović. 2019. "Investigation of $\mathrm{ZnFe} 2 \mathrm{O} 4$ Spinel Ferrite Nanocrystalline Screen-printed Thick Films for Application in Humidity Sensing." International Journal of Applied Ceramic Technology. https://doi.org/10.1111/ijac.13190.

This work is licensed under a Creative Commons Attribution Non Commercial No

Derivatives 4.0 license 
Article type : Article

\section{Investigation of $\mathrm{ZnFe}_{2} \mathrm{O}_{4}$ spinel ferrite nanocrystalline screen-printed thick}

\section{films for application in humidity sensing}

Maria V. Nikolic ${ }^{1 *}$, Zorka Z. Vasiljevic ${ }^{2}$, Miloljub D. Lukovic ${ }^{1}$, Vera P. Pavlovic ${ }^{3}$, Jugoslav B. Krstic ${ }^{4}$, Jelena Vujancevic ${ }^{2}$, Nenad Tadic $^{5}$, Branislav Vlahovic $^{6}$, Vladimir B. Pavlovic $^{2}$

${ }^{1}$ Institute for Multidisciplinary Research, University of Belgrade, Kneza Viseslava 1, 11030, Belgrade, Serbia

${ }^{2}$ Institute of Technical Sciences of SASA, Knez Mihailova 35, 11000 Belgrade, Serbia

${ }^{3}$ University of Belgrade, Faculty of Mechanical Engineering, Kraljice Marije 16, 11000 Belgrade,

Serbia

${ }^{4}$ Institute of Chemistry, Technology and Metallurgy, Department of Catalysis and Chemical Engineering, University of Belgrade, Studentski trg 12-16/III, 11000 Belgrade, Serbia

${ }^{5}$ University of Belgrade, Faculty of Physics, Studentski trg 12, 11000 Belgrade, Serbia

${ }^{6}$ North Carolina Central University, 18001 Fayeteville Street, Durham, NC 27707, USA

*corresponding author mariav@rcub.bg.ac.rs

This article has been accepted for publication and undergone full peer review but has not been through the copyediting, typesetting, pagination and proofreading process, which may lead to differences between this version and the Version of Record. Please cite this article as doi: 10.1111/ijac. 13190

This article is protected by copyright. All rights reserved. 


\section{Abstract}

Zinc ferrite nanocrystalline powder was obtained by solid state synthesis of starting zinc oxide and hematite nanopowders. Field emission scanning electron microscopy (FESEM and transmission electron microscopy (TEM), X-ray diffraction (XRD), X-ray photoelectron spectroscopy (XPS) and Raman spectroscopy confirmed the formation of nanocrystalline zinc-ferrite powder with a mixed spinel structure with small amounts of remaining zinc oxide and hematite as impurities. Thick film paste was formed and screen printed on test interdigitated PdAg electrodes on alumina substrate. Formation of a porous nanocrystalline structure was confirmed by scanning electron microscopy (SEM) and Hg porosimetry. Humidity sensing properties of zinc ferrite thick films were investigated by monitoring the change in impedance in the relative humidity interval $30-90 \%$ in the frequency range $42 \mathrm{~Hz}-1 \mathrm{MHz}$ at room temperature $\left(25^{\circ} \mathrm{C}\right)$ and $50{ }^{\circ} \mathrm{C}$. At $42 \mathrm{~Hz}$ at both analyzed temperatures the impedance reduced $\sim 46$ times in the humidity range $30-90 \%$. The dominant influence of grain boundaries was confirmed by analysis of complex impedance with an equivalent circuit.

Keywords: zinc ferrite, thick film, electrical properties, humidity sensor

\section{INTRODUCTION}

With continued industrial progress and overall increase in pollution, gas detection continues to have a very important role through monitoring and control in environment protection, safety in households and industry and many other aspects of human life ${ }^{1}$. Humidity monitoring and control is significant for quality control, plant cultivation and in many other industrial fields ${ }^{2}$. Metal oxide semiconductor gas sensor materials have been intensively investigated over the last 50 years. This research has involved a wide variety of metal oxides such as $\mathrm{TiO}_{2}, \mathrm{WO}_{3}, \mathrm{Fe}_{2} \mathrm{O}_{3}$ (transition metal-

This article is protected by copyright. All rights reserved. 
oxides), $\mathrm{ZnO}, \mathrm{SnO}_{2}$ (post-transition metals) ${ }^{1}$. Metal oxide gas sensors have shown high sensitivity, fast response, long term stability, high selectivity, low cost and are simple. Complex oxides, such as spinel oxides and especially spinel ferrites (unit formula $\mathrm{AB}_{2} \mathrm{O}_{4}$ ) are very promising materials for sensing different gases, even though they have been much more widely applied as magnetic materials. Spinel ferrites have shown sensitivity to a wide variety of gases, such as $\mathrm{H}_{2} \mathrm{O}$ (humidity), $\mathrm{CO}$, ethanol, acetone, $\mathrm{VOCs}^{3-8}$.

The spinel structure with an $\mathrm{AB}_{2} \mathrm{O}_{4}$ unit formula represents a cubic crystal system with 32 closely packed oxygen atoms with 64 tetrahedral sites and 32 octahedral sites. In spinel ferrites the general formula is $\mathrm{MFe}_{2} \mathrm{O}_{4}$. Depending on the balance between $\mathrm{M}^{2+}$ and $\mathrm{Fe}^{3+}$ cations on 8 tetrahedral and 16 octahedral sites three spinel structures are possible: normal where all $M^{2+}$ divalent cations are on the tetrahedral sites and trivalent $\mathrm{Fe}^{3+}$ cations are on octahedral sites, inverse where divalent cations occupy octahedral sites and trivalent cations are equally distributed on remaining octahedral sites and tetrahedral sites, and mixed where both $\mathrm{M}^{2+}$ and $\mathrm{Fe}^{3+}$ cations randomly occupy both octahedral and tetrahedral sites ${ }^{1,9}$.

Conventionally $\mathrm{ZnFe}_{2} \mathrm{O}_{4}$ has a normal spinel structure with $\mathrm{Zn}^{2+}$ cations occupying octahedral sites ${ }^{10}$. However, the cation distribution in spinel ferrites and thus zinc-ferrite, is greatly influenced by the synthesis procedure, especially when nanosized particles are obtained ${ }^{11-15}$. Nanosized zincferrite particles have a mixed spinel structure, with the inversion parameter depending on the synthesis route ${ }^{9}$. Particle size, morphology, structure and the inversion parameter greatly influence the resulting properties of nanoscale zinc ferrite, enhancing and broadening the potential application of this material besides magnetic devices to drug delivery, photocatalysis, antifungal activity and gas sensing $5,13,14,16,17$.

Modification of $\mathrm{ZnFe}_{2} \mathrm{O}_{4}$ with ion substitution or forming composites with other materials further enhances the properties of this spinel ferrite for a wide range of applications, such as gas sensor, semiconductor photocatalyst and cathode material in lithium ion batteries ${ }^{10}$. Thus,

This article is protected by copyright. All rights reserved. 
significantly improved photoelectrochemical activity was obtained for $\mathrm{ZnFe}_{2} \mathrm{O}_{4} / \alpha-\mathrm{Fe}_{2} \mathrm{O}_{3}$ heterojunction arrays ${ }^{18}$. Enhanced gas sensing performance has been achieved for $\mathrm{ZnO} / \mathrm{ZnFe}_{2} \mathrm{O}_{4}$ composite nanoheterostructures ${ }^{19-21}$. The influence of magnesium substitution in nanoparticle zinc ferrites on the humidity response and sensitivity was investigated by Patil et al ${ }^{4}$.

The gas sensing mechanism of spinel ferrite oxides is well known ${ }^{1,16,17}$. It is a surface-related mechanism where a porous structure offers more active sites accessible for sensing reactions ${ }^{16,17}$. In theory spinel ferrites are predisposed to good sensing performance due to the difference in size between, for example, $\mathrm{Zn}(\mathrm{II})$ and $\mathrm{Fe}(\mathrm{III})$ cations, electronegativity and other properties, so they are capable of chemisorbing more oxygen than other metal oxides ${ }^{16}$. Physicochemical characteristics of spinel ferrites can be tuned due to the differences in geometry and ion bonding energy between cations and surrounding oxygen ions in octahedral and tetrahedral polyhedron ${ }^{1}$. In $\mathrm{ZnFe}_{2} \mathrm{O}_{4}$ changes to the cation positioning in the spinel structure from normal to mixed, establish conditions for improved gas sensing properties of mixed spinel $\mathrm{ZnFe}_{2} \mathrm{O}_{4}{ }^{1}$. One issue is instability of $\mathrm{Zn}^{2+}$ cations in octahedral sites at temperatures higher than $300{ }^{\circ} \mathrm{C}$, and this prevents exploitation of $\mathrm{ZnFe}_{2} \mathrm{O}_{4}$ in many gas sensors. However, humidity sensing does not occur at high temperatures, but most often at temperatures close to room temperature. In their recent work Xu et al. ${ }^{2}$ obtained a high humidity response of sol-gel synthesized $\mathrm{ZnFe}_{2} \mathrm{O}_{4}$ thin films. In this work we have synthesized nanocrystalline zinc ferrite powder with small amounts of zinc oxide and hematite as impurities, using a simple solid state procedure. It was used to form thick film paste that was screen printed on test interdigitated PdAg electrodes on alumina substrate. The aim was to analyze the influence of humidity on impedance response in view of potential application of this low cost simple method and versatile material in humidity sensing.

This article is protected by copyright. All rights reserved. 


\section{EXPERIMENTAL}

\subsection{Materials}

Starting commercial nanopowders of $\mathrm{ZnO}$ (Chempur, 99.5\%, grain size $20 \mathrm{~nm}$ ) and $\alpha-\mathrm{Fe}_{2} \mathrm{O}_{3}$ (hematite, Alfa Aesar 99\%, grain size 20-60 nm) in the appropriate molar ratio to form $\mathrm{ZnFe}_{2} \mathrm{O}_{4}$ were homogenized in a planetary ball mill for $15 \mathrm{~min}$ and calcined at $900^{\circ} \mathrm{C}$ for $2 \mathrm{~h}$, and the obtained powder was then sieved through a $38 \mu \mathrm{m}$ (400 mesh) sieve.

Thick film paste was prepared by the addition of organic agents to $6 \mathrm{gr}$ of the synthesized powder following the procedure described by 1 to et $\mathrm{al}^{22}$. The organic agents used were $30 \mathrm{ml}$ of anhydrous ethanol as a solvent, $20 \mathrm{~g}$ of alpha-terpineol (95\% min, Alfa Aesar) as an organic solvent and $3 \mathrm{~g}$ of ethyl-cellulose (viscosity $4 \mathrm{cP}$, Aldrich Chemistry) as a binder. The combination of $1 \mathrm{ml}$ acetic acid (MOS HEMOS, pro analysis) and $5 \mathrm{ml}$ of distilled water was used to peptize the paste. An ultrasonic horn (Bandelin Sonoplus 2070HD) was used for homogenization. Alpha terpineol was added as an organic solvent as it gives long-term stability and reproducible results compared to water-based pastes ${ }^{22}$. The combination of water and acetic acid acted as aggregation blockers and adhesion enhancers ${ }^{22,23}$

Interdigitated PdAg electrodes were screen printed on alumina substrate and fired in a conveyor furnace at $850^{\circ} \mathrm{C}$ for 10 minutes in air. The analyzed electrode spacing was 0.2 and 0.25 $\mathrm{mm}$. Four layers of paste were then screen printed on the prepared alumina substrate with interdigitated PdAg electrodes. Each layer was dried for 15 minutes at $60^{\circ} \mathrm{C}$, before the next layer was printed. The average layer thickness was estimated to be $12-15 \mu \mathrm{m}$, so the resulting thick film thickness was estimated to be $\sim 55 \mu \mathrm{m}$. The sensors were heat treated in air in a furnace at $600^{\circ} \mathrm{C}$ for 30 minutes. An example of a thick film test sample is shown in Figure 1.

This article is protected by copyright. All rights reserved. 


\subsection{Structural characterization}

X-ray diffraction (XRD) analysis of the obtained zinc ferrite powder was performed on a Philips PW 1050 diffractometer with $\mathrm{CuK}_{\alpha}$ radiation, step $0.02 \mathrm{~s}$ and holding time $10 \mathrm{~s}$. XRD analysis of the thick film material (powder) peeled off the sensor substrate was performed on a Rigaku Ultima IV diffractometer. Structural refinement was performed using the Rietveld method with the GSAS II package ${ }^{24}$. Samples were analyzed for the presence of $\mathrm{ZnFe}_{2} \mathrm{O}_{4}$ with a mixed cubic spinel structure, using starting parameters given by Waerenborgh et $\mathrm{al}^{25}$ (ICSD 75104, $a=8.4409$, inversion parameter 0.201$), \mathrm{ZnO}$ and $\alpha-\mathrm{Fe}_{2} \mathrm{O}_{3}$ (hematite).

Transmission electron microscopy (TEM) of the obtained powder was performed on a JEOL JEM-1400 PLUS device.

Hg porosimetry measurements were performed in order to determine textural parameters of the synthetized $\mathrm{ZnFe}_{2} \mathrm{O}_{4}$ powder and thick film (denoted as $\mathrm{tf}-\mathrm{ZnFe}_{2} \mathrm{O}_{4}$ ) obtained by peeling material (powder) off the sensor substrate after paste preparation procedure and calcination. This will enable estimation of the overall influence of the preparation procedure on the porosity of thick film sensor material.

A CD3-P type dilatometer was used for measurement of both samples in the pressure range from 0.1 to $200 \mathrm{MPa}$, for which the blank volume value (compressibility of mercury and dilatometer parts) was determined.

Bulk density measurements $\left(\rho_{b 1}\right)$ of samples were performed on a Macropore Unit 120 (Fisons Instruments) using mercury as the displacing fluid. Prior to analysis the sample was dried in an oven at 110 o $\mathrm{C}$ during $24 \mathrm{~h}$ and additionally evacuated in a sample holder at the analytical position for $2 \mathrm{~h}$. Mercury porosimetry measurements were performed on a High pressure unit PASCAL 440 (Thermo Fisher) within the same pressure range as blank measurement. For each sample two intrusion-extrusion runs (R1 and R2), one after the other, were conducted. Automatic

This article is protected by copyright. All rights reserved. 
data acquisition of intrusion-extrusion runs vs. applied pressure values was obtained through the SOLID Software System interface for a PC. The SOLver Ver. 1.3.4 software was used for calculation of parameters obtained from $\mathrm{Hg}$ porosimetry measurement: total cumulative volume $\left(\mathrm{V}_{\text {tot }}\right)$, apparent density $\left(\rho_{\text {App }}\right)$ at maximal intrusion pressure, specific surface area and porosity. The same values of mercury surface tension $(0.48 \mathrm{~N} / \mathrm{m})$ and contact angle $\left(140^{\circ}\right)$ were used for all calculations. The proper value of mercury density was used for all individual runs depending on the $\mathrm{Hg}$ temperature of specific measurement. In all measurement The value of true density $\left(5.38 \mathrm{~g} / \mathrm{cm}^{3}\right)$ was obtained in all measurements by calculating from XRD data taking account the mass percent of all phases present in the synthetized materials $\left(\mathrm{ZnFe}_{2} \mathrm{O}_{4}, \alpha-\mathrm{Fe}_{2} \mathrm{O}_{3}\right.$ and $\left.\mathrm{ZnO}\right)$.

Field-emission scanning electron microscopy (FESEM) of the starting powder and thick films was performed on a TESCAN MIRA3 XM FESEM device.

Scanning electron microscopy (SEM) images of the thick film surface were recorded on a TESCAN Electron Microscope VEGA TS 5130MM device.

X-ray photoelectron (XPS) spectra measurements were conducted on a Kratos Axis Ultra XPS system. The X-Ray source was monochromated Aluminum K-alpha X-Ray with a source voltage of 15 $\mathrm{kV}$ and current of $10 \mathrm{~mA}$. All survey scans were performed with pass energy of $160 \mathrm{eV}$, and all region scans were performed with pass energy of $20 \mathrm{eV}$. All data was calibrated to the $\mathrm{C}-\mathrm{C}$ portion of the $\mathrm{C} 1 \mathrm{~s}$ peak at $284.5 \mathrm{eV}$.

Raman spectra of the starting $\mathrm{ZnO} / \mathrm{Fe}_{2} \mathrm{O}_{3}$ powder mixture and the synthesized $\mathrm{ZnFe}_{2} \mathrm{O}_{4}$ powder were recorded on a Horiba Jobin Yvon LabRam HR evolution spectrometer in backscattering geometry in the range $100-1500 \mathrm{~cm}^{-1}$ with a He-Ne laser $(632.8 \mathrm{~nm})$, grating 1800 lines $/ \mathrm{mm}$, slit 100, power at sample of 0.4 and $1 \mathrm{~mW}$ and acquisition $20 \mathrm{~s} / 5$ cycles.

This article is protected by copyright. All rights reserved. 


\subsection{Testing of Humidity Response}

Change of impedance of zinc ferrite thick film samples was measured in a JEIO TECH TH-KE025 Temperature and humidity climatic chamber in the frequency range $42 \mathrm{~Hz}-1 \mathrm{MHz}$ on a $\mathrm{HIOKI}$ 3532-50 LCR HiTESTER device. The relative humidity was varied from 30 to $90 \%$. Measurements were conducted at two operating temperatures 25 and $50^{\circ} \mathrm{C}$. The sample was placed into the chamber and impedance was measured using wires soldered to the electrodes. Prior to each measurement the sample was dried for 20 minutes at $50^{\circ} \mathrm{C}$ to remove any excess moisture. The chamber was set to the desired temperature and when this was achieved (on average 30-60 minutes) the humidity was varied from 30 to $90 \%$ and back. Impedance was measured after the set humidity value was achieved/stabilized (on average 45-90 minutes). This cycle was repeated for each analyzed sample.

\section{RESULTS AND DISCUSSION}

\subsection{Structural and morphological analysis of $\mathrm{ZnFe}_{2} \mathrm{O}_{4}$ powder}

Rietveld refinement of the XRD of the obtained powder (Figure 2) showed that it contained $\mathrm{ZnFe}_{2} \mathrm{O}_{4}$ with a mixed spinel structure, and small amounts of unreacted $\mathrm{ZnO}$ and $\mathrm{Fe}_{2} \mathrm{O}_{3}$ (hematite). Determined structural parameters (cell parameters, atomic positions, isotropic thermal displacement, occupancies and average oxygen-metal distances) from Rietveld refinement and crystallite sizes calculated using the Sherrer equation are given in Table 1.

The general formula for a spinel ferrite is $\left(\mathrm{Me}_{1-x}^{2+} \mathrm{Fe}_{x}^{3+}\right)_{A}\left[\mathrm{Fe}_{2-x}^{3+} \mathrm{Me} e_{x}^{2+}\right]_{B} \mathrm{O}_{4}$ with the divalent atom $\mathrm{Me}(\mathrm{Zn}, \mathrm{Ni}, \mathrm{Mg}, \mathrm{Mn}, \mathrm{Co}$, Fe etc.) occupying either tetrahedral $(A-8 a)$ or octahedral $(B-16 d)$ sites, where $x$ denotes the inversion parameter ${ }^{26}$. When $x=0$, the divalent atoms are all located on the tetrahedral sites and the spinel is normal. When $x=1$, the divalent atoms are all located on octahedral sites and the spinel is inverse. All other variations of $x$ can be defined as mixed (random)

This article is protected by copyright. All rights reserved. 
spinel. Zinc ferrite in bulk form is a normal spinel, where divalent non-magnetic $\mathrm{Zn}^{2+}$ ions preferentially occupy tetrahedral (A) sites and all $\mathrm{Fe}^{3+}$ ions occupy octahedral sites ${ }^{12}$. However, in nanocrystalline $\mathrm{ZnFe}_{2} \mathrm{O}_{4} \mathrm{Zn}^{2+}$ and $\mathrm{Fe}^{3+}$ cations are distributed on both octahedral and tetrahedral sites leading to a mixed spinel structure resulting in enhanced magnetic, electric and gas sensing properties $^{10-17}$.

Analysis of the determined structural parameters given in Table 1 shows that the inversion parameter in our powder was 0.4 (denoting the occupancy of $\mathrm{Fe}^{3+}$ ions on tetrahedral sites) indicating a mixed spinel structure where $40 \% \mathrm{Fe}^{3+}$ ions are located on tetrahedral sites, i.e. $40 \% \mathrm{Zn}^{2+}$ ions are located on octahedral sites. The determined lattice parameter for zinc-ferrite was also relatively low ( $a=8.42742 \AA$ ) and this according to literature data ${ }^{26}$ can be an indication of cation inversion due to the differences in ionic radius between $\mathrm{Zn}^{2+}$ and $\mathrm{Fe}^{3+}$ ions. Thus, Pradeep et $\mathrm{al}^{11}$ obtained a lattice parameter of $8.429 \AA$ for nanocrystalline zinc ferrite and the inversion degree of 0.35. Lemine et al. ${ }^{27}$ also explained reduction of the lattice parameter from 8.448 to $8.427 \AA$ by redistribution of $\mathrm{Zn}^{2+}$ and $\mathrm{Fe}^{3+}$ ions within interstitial states resulting in changes in magnetic properties. Reduction of the lattice parameter can also be attributed to the presence of lattice defects $^{26}$. Yadav et al ${ }^{12}$ also associated variation in the lattice constant with distortion in the lattice and redistribution of cations. However, it has been shown that XRD is not the best method to deal with cation occupation ${ }^{26}$. The cation occupation in spinels has been determined by a variety of other methods, such as X-ray photoelectron spectroscopy, Raman spectroscopy, neutron diffraction and others ${ }^{1}$.

Rietveld refinement of the XRD of the thick film powder peeled off the substrate (Figure 2) showed that the structure remained the same including the phase composition and amounts and also inversion parameter. No new phase was noted.

FESEM and TEM images of the obtained zinc-ferrite powder are shown in Figure 3. The powder grain size had an average grain size of around $200 \mathrm{~nm}$.

This article is protected by copyright. All rights reserved. 
Figure 4a shows the measured XPS spectra of zinc-ferrite powder. This technique is most often used to study structural inversion in $\mathrm{ZnFe}_{2} \mathrm{O}_{4}{ }^{28}$. Deconvolution of the $\mathrm{Zn} 2 \mathrm{p}_{3 / 2}$ peak was performed in the $\mathrm{Zn} 2 \mathrm{p}$ spectra as shown in Figure $4 \mathrm{~b}$. The peak at $1021.2 \mathrm{eV}$ can be attributed to $\mathrm{Zn}^{2+}$ occupying tetrahedral sites in zinc ferrite. The smaller peak at $1022.3 \mathrm{eV}$ is close to literature values for $\mathrm{BE} Z \mathrm{Zn} 2 \mathrm{p}_{3 / 2}$ in the cases when $\mathrm{Zn}^{2+}$ occupies octahedral sites ${ }^{29,30}$. Sutka et al ${ }^{27}$ estimated

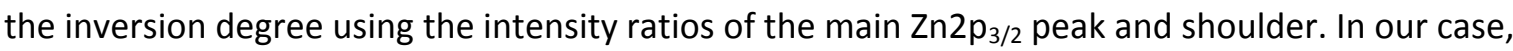
due to the presence of unreacted $\mathrm{ZnO}$ in the powder (even though this amount is small), according to Bera et $\mathrm{al}^{30}$, the $\mathrm{Zn} 2 \mathrm{p}_{3 / 2}$ peak shape is due to the presence of three types of $\mathrm{Zn}^{2+}: \mathrm{Zn}^{2+}$ on tetrahedral sites (normal spinel), $\mathrm{Zn}^{2+}$ in the oxide and $\mathrm{Zn}^{2+}$ in octahedral sites so estimation of the inversion degree was not possible. However, XPS results confirm the results of XRD analysis that the obtained zinc-ferrite powder has a mixed spinel structure.

The asymmetrical complex peak of the O1s spectrum (Figure 4c) can be decomposed into three peaks. The peak obtained at $\sim 529.7 \mathrm{eV}$ after deconvolution corresponds to lattice oxygen and is characteristic of oxygen inside the $(\mathrm{Fe} / \mathrm{Zn})-\mathrm{O}$ framework. The peaks obtained at $\sim 530.8 \mathrm{eV}$ and $\sim 532 \mathrm{eV}$ can be attributed to the existence of adsorbed oxygen on the sample surface. This marks active surface oxygen species, including surface oxygen of adsorbed oxygen species, weakly bonded oxygen and hydroxyl-like groups ${ }^{31-33}$.

Fe2p spectra have two peaks (Figure $4 d$ ) that can be attributed to the existence of Fe2 $p_{3 / 2}$ and Fe2 $\mathrm{p}_{1 / 2}$. Satellite peaks are also noted at $\sim 719.8 \mathrm{eV}$ and $\sim 733 \mathrm{eV}$. The positions of the two peaks and their satellites at $\mathrm{BE}$ higher for $\sim 8 \mathrm{eV}$ indicate the $\mathrm{Fe}^{3+}$ oxidation state in the analyzed powder ${ }^{34}$.

Raman spectra of the synthesized $\mathrm{ZnFe}_{2} \mathrm{O}_{4}$ powder for two powers of 0.4 and $1 \mathrm{~W}$ at the sample are shown in Figure 5. In the measured spectra of $\mathrm{ZnFe}_{2} \mathrm{O}_{4}$ powder four first order modes are clearly noticeable for both applied laser intensities. Zinc ferrite with a spinel structure (space group $F d 3 m$ ) has five active Raman modes $\left(\mathrm{A}_{1 \mathrm{~g}}+\mathrm{E}_{\mathrm{g}}+3 \mathrm{~F}_{2 \mathrm{~g}}\right)$, but the first two modes (at lower frequencies) are often not clearly noticeable for nanoparticle zinc ferrite ${ }^{35-37}$.

This article is protected by copyright. All rights reserved. 
The width and shape (asymmetry) of the first order Raman peaks show participation of the inverse spinel structure (space group $\mathrm{P}_{3} 22$ ) besides the dominant spinel structure. This is further confirmation of the existence of a mixed spinel structure, with $\mathrm{Zn}^{2+}$ and $\mathrm{Fe}^{3+}$ cations occupying both tetrahedral and octahedral sites, as was noted by XRD and XPS analysis. For simplicity, modes in Figure 5 for zinc-ferrite were assigned in accordance with the spinel structure. In nanocrystal samples the origin of Raman peak asymmetry can be the confinement effect. The most expressed zinc-ferrite mode $\left(A_{1 g}\right)$ corresponds to symmetrical stretching vibrations of oxygen atoms along Fe-O (at higher frequencies as part of the complex asymmetric peak) and $\mathrm{Zn}-\mathrm{O}$ bonds (at lower frequencies as part of the complex asymmetric peak) in tetrahedral coordination $\mathrm{MO}_{4}$, where $\mathrm{M}=\mathrm{Fe}$, $\mathrm{Zn}^{31}$. Though some authors state that modes below $600 \mathrm{~cm}^{-1}$ generally originate from vibrations of the octahedral group in the mixed spinel structure ${ }^{35,38}$, other literature data indicates $F_{2 g}(2)$ and $F_{2 g}(3)$ modes. The $E_{g}$ mode corresponds to symmetrical bending vibrations of oxygen in relation to cations in a tetrahedral surrounding, while the $F_{2 g}(1)$ mode corresponds to translational vibrations of the whole tetrahedra ${ }^{9}$.

The two strongest modes of remaining hematite can be noted weakly in zinc-ferrite spectra confirming XRD analysis. The presence of the $E_{2}$ (high) mode of remaining zinc-oxide is not so obvious as it is overlapped with the $\mathrm{F}_{2 \mathrm{~g}}(3)$ mode of $\mathrm{ZnFe}_{2} \mathrm{O}_{4}$, but the presence of $\mathrm{ZnO}$ was previously confirmed by XRD analysis. The wide peak at $1290-1300 \mathrm{~cm}^{-1}$ can partly originate from remaining hematite, but also from multiphonon processes relating to zinc-ferrite ( $2 \mathrm{~A}_{1 \mathrm{~g}}$ mode). The peak at $1050-1060 \mathrm{~cm}^{-1}$ corresponding to the $2 \mathrm{~F}_{2 \mathrm{~g}}(3)$ mode can also be attributed to multiphonon processes in zinc-ferrite ${ }^{39}$. The wide peak in the $1100-1130 \mathrm{~cm}^{-1}$ region increases with increase in laser strength. This peak can be attributed to zinc-ferrite ${ }^{37}$.

The results of $\mathrm{Hg}$ porosimetry measurements are shown on Fig 6 as well as in Table II.

The bulk density obtained from the first run indicate the existence of loose powder organization that is more pronounced in the tf- $\mathrm{ZnFe}_{2} \mathrm{O}_{4}$ sample $\left(\rho_{b \mid} \mathrm{f}-\mathrm{ZnFe}_{2} \mathrm{O}_{4}<\rho_{b \mid} \mathrm{ZnFe}_{2} \mathrm{O}_{4}\right)$.

This article is protected by copyright. All rights reserved. 
The difference in total cumulative volume $\left(\Delta \mathrm{V}_{\text {tot }}\right)$ between the two runs is an obvious feature of measurements for both materials. This is not surprising taking into account that both materials transferred to the sample holder for porosimetry measurements are powders. Therefore, in first runs the applied pressure forced mercury to compact powders beside intrusion in pore system ${ }^{40,41}$.

The somewhat higher specific surface area of the tf- $\mathrm{ZnFe}_{2} \mathrm{O}_{4}$ sample compared to $\mathrm{ZnFe}_{2} \mathrm{O}_{4}$, for any pair of cyclic measurement, indicates that a deagglomeration and rearrangement process of fine particles occurs during the thick film paste preparation procedure.

Despite different values of $\mathrm{V}_{\text {tot }}$ obtained for the initial runs, $\Delta \mathrm{V}_{\text {tot }}$ for both materials is almost equal $\left(\approx 0.16 \mathrm{~cm}^{3} / \mathrm{g}\right)$. During the first run mercury penetrates pores and after relaxation of pressure mercury withdraws enabling determination of the total volume of pores, while the second run enables determination of the volume of intra-agglomerate pores ${ }^{42}$. Inter-agglomerate pores are eliminated during the first penetration, but intra-agglomerate pores remain. If we compare the porosity values obtained for $\mathrm{ZnFe}_{2} \mathrm{O}_{4}$ initial powder and tf- $\mathrm{ZnFe}_{2} \mathrm{O}_{4}$ the amount of intruded $\mathrm{Hg}$ corresponding to intra-particle porosity during R-2 (true pore system of materials intact during R-1) for tf- $\mathrm{ZnFe}_{2} \mathrm{O}_{4}$ is higher than for initial $\mathrm{ZnFe}_{2} \mathrm{O}_{4}$. Taking into account that $\mathrm{V}_{\text {tot }}-\mathrm{R}^{2}$ of $\mathrm{tf}-\mathrm{ZnFe}_{2} \mathrm{O}_{4}$ is significantly higher than the corresponding value obtained for $\mathrm{ZnFe}_{2} \mathrm{O}_{4}$ it can be concluded that the applied procedure of thick film paste prevented particle aggregation resulting in an increase in porosity. This is consistent with the finding of Ito et $\mathrm{a}^{22}$ about the beneficial influence of acetic acid acting as a dispersant in the process of fabrication of $\mathrm{TiO}_{2}$ screen-printing pastes.

The values obtained for the pore size distribution from two successive measurements of both $\mathrm{ZnFe}_{2} \mathrm{O}_{4}$ materials to some extent reveals the particle arrangement and organization in the analyzed ferrite materials, as well as the effect of the thick film preparation process on the characteristics of tf- $\mathrm{ZnFe}_{2} \mathrm{O}_{4}$.

This article is protected by copyright. All rights reserved. 
The PSD curve of Run 1 of the $\mathrm{ZnFe}_{2} \mathrm{O} 4$ powder sample obtained by solid state synthesis has two broad regions with peaks around $2.6 \mu \mathrm{m}$ and $120 \mathrm{~nm}$ (Fig. 6-left). Absence of a region with a maximum of $2.6 \mu \mathrm{m}$ on the PSD curve of Run 2 indicates that its origin on the PSD curve of Run 1 is in association with very loose particles present in $\mathrm{ZnFe2O4}$ powder, which cannot be maintained during $\mathrm{Hg}$ intrusion in the first run. On the other hand, the almost identical distribution for both measurement cycles in the region below $500 \mathrm{~nm}$, (maxima around $120 \mathrm{~nm}$ ) are proof the existence of a permanent, rigid pore system maintained for all applied pressure.

The PSD curves of $\mathrm{tf}-\mathrm{ZnFe}_{2} \mathrm{O}_{4}$ (Figure 6-right) also have a bimodal distribution, but both regions are moved to slightly lower values of diameters with peaks at about $0.5 \mu \mathrm{m}$ and $90 \mathrm{~nm}$. Comparison of curves for R1 measurements of both materials shows that there is a certain redistribution of the pore system in $\mathrm{tf}-\mathrm{ZnFe}_{2} \mathrm{O}_{4}$ in relation to $\mathrm{ZnFe}_{2} \mathrm{O}_{4}$ powder. However, the shape of the Run 2 curve of tf-ZnFe2O4 is preserved in comparison with the Run 1 curve, which is certainly the consequence of the applied thick film preparation. Overall, although there is a certain decrease in porosity values of the tf- $\mathrm{ZnFe}_{2} \mathrm{O}_{4}$ sample for $\mathrm{R} 2$ measuring, its value is still high (almost $60 \%$ ).

\subsection{Humidity sensing analysis and mechanism}

The measured impedance of $\mathrm{ZnFe}_{2} \mathrm{O}_{4}$ thick film samples decreased with increase in frequency at both operating temperatures $\left(25\right.$ and $\left.50^{\circ} \mathrm{C}\right)$. Smaller electrode spacing $(0.2 \mathrm{~mm})$ of the test electrodes gave better results in view of the change of impedance with humidity. The change of impedance with frequency in the relative humidity $(\mathrm{RH})$ range $30-90 \%$ for test electrodes with 0.2 $\mathrm{mm}$ spacing is shown in Figure 7. As the relative humidity increased the impedance also decreased, that was more expressed for higher relative humidity, as shown in Figure 8 . Thus, at $42 \mathrm{~Hz}$ the measured impedance decreased $\sim 46$ times from $38.7 \mathrm{M} \Omega$ at relative humidity $(\mathrm{RH})$ of $30 \%$ to 0.83

This article is protected by copyright. All rights reserved. 
$\mathrm{M} \Omega$ at $\mathrm{RH}$ of $90 \%$ measured at $25^{\circ} \mathrm{C}$, and at $50^{\circ} \mathrm{C}$ from $35.9 \mathrm{M} \Omega$ at $\mathrm{RH}$ of $30 \%$ to $0.77 \mathrm{M} \Omega$ at $\mathrm{RH}$ of $90 \%$.

The sensor response (sensitivity $-S$ ) can be defined as the change in resistance of the material on exposure to gas. It can be represented in different forms as: $S=R_{a} / R_{g} ; S=R_{g} / R_{a} ; S=\Delta R / R_{g}$ or $S=\Delta R / R_{a}$, where $\Delta R=\left|R_{a}-R_{g}\right|, R_{a}$ is the sensor resistance in ambient air and $R_{g}$ is the sensor resistance in the target gas ${ }^{43}$. We determined the sensitivity as:

$$
S=\frac{|Z|_{L H}-|Z|_{H}}{|Z|_{L H}} \times 100
$$

where $|Z|_{L H}$ is the impedance measured at the lowest analyzed humidity and $|Z|_{H}$ is the impedance measured for different humidity values in the chamber. The calculated sensitivity using eq. [1] for $\mathrm{ZnFe}_{2} \mathrm{O}_{4}$ thick film samples at 25 and $50^{\circ} \mathrm{C}$ measured in the relative humidity range $30-90 \%$ is shown in Figure 8. With increase in humidity the sensitivity increases and this change is similar at both room temperature $\left(25^{\circ} \mathrm{C}\right)$ and the analyzed slightly elevated temperature of $50^{\circ} \mathrm{C}$.

In the case of humidity sensing ${ }^{4,5}$ at low humidity water molecules are chemisorbed onto available active oxygen sites forming a monolayer of $\mathrm{OH}$ groups ${ }^{1}$. With increase in humidity water molecules are physisorbed on the chemisorbed layer. Adsorbed water molecules are hydrogenbonded to two hydroxyl groups, making $\mathrm{H}_{3} \mathrm{O}^{+}$the dominant surface charge carrier ${ }^{5}$. Further increase in humidity levels leads to multi physisorbed layers and formation of a liquid-like multilayer film of hydrogen-bonded water molecules. In this case low energy is required for hopping between adjacent water molecules, resulting in an increase in ionic conductivity that can be explained by the Grotthuss charge mechanism ${ }^{44}: \mathrm{H}_{2} \mathrm{O}+\mathrm{H}_{3} \mathrm{O}^{+} \rightarrow \mathrm{H}_{3} \mathrm{O}^{+}+\mathrm{H}_{2} \mathrm{O}$. Electrical charge transport occurs through a chemical chain reaction process ${ }^{2}$ with $\mathrm{H}_{3} \mathrm{O}^{+}$releasing a proton to a nearby $\mathrm{H}_{2} \mathrm{O}$ molecule that is ionized and forms another $\mathrm{H}_{3} \mathrm{O}^{+}$resulting in hopping of protons from one water molecule to another. Electrolytic conductivity becomes dominant at high humidity levels ${ }^{1}$.

This article is protected by copyright. All rights reserved. 
In our case we obtained nanocrystalline $\mathrm{ZnFe}_{2} \mathrm{O}_{4}$ with a mixed spinel structure confirmed by XRD, XPS and Raman measurements. The ferrimagnetic order in mixed spinel zinc-ferrite due to changes in cation positioning showed besides room temperature magnetic behavior, improved gas sensing properties compared to normal spinel zinc-ferrite ${ }^{1,28}$. This can be applied to humidity sensing. Our powder also contained small amounts of unreacted $\mathrm{ZnO}$ and $\alpha-\mathrm{Fe}_{2} \mathrm{O}_{3}$ as impurities and their presence also had an influence on change of impedance and sensitivity to humidity. Hematite is a transition metal oxide with multivalent cations that are very sensitive and can be oxidized and reduced by a change in oxidation state ${ }^{1}$. The presence of hematite could improve humidity sensing properties. $\mathrm{ZnO}$ is a $\mathrm{d}^{10}$ oxide ( $\mathrm{Zn}$ has a filled $\mathrm{d}^{10}$ shell) with localized donor levels in the bandgap caused by oxygen vacancies and interstitial $\mathrm{Zn}$ atoms in the lattice ${ }^{44}$. This type of oxide can be reduced by altering the $\mathrm{d}^{10}$ cation electron configuration, where cations can act as donors, acceptors or interstitials ${ }^{1}$. Free charge carriers can be created when oxygen vacancies are formed. $\mathrm{ZnO}$ is a low cost, stable and promising gas sensing material, but with drawbacks such as poor sensitivity and selectivity ${ }^{1,20}$. Improved gas sensing properties have been achieved for $\mathrm{ZnFe}_{2} \mathrm{O}_{4} / \mathrm{ZnO}$ heterojunctions $\mathrm{s}^{20,21}$, so the presence of $\mathrm{ZnO}$ in our powder could also contribute to improving humidity sensing properties by increasing the number of oxygen vacancies that are active sites for dissociation of the water molecule ${ }^{45}$. Obviously, the individual influence of hematite and zinc-oxide needs to be investigated in detail, taking into account the separate influence of each material and will be the subject of further research.

The response and sensitivity of humidity sensors is most often related to the morphology and has focused on the specific surface area, grain size and porosity ${ }^{1}$. Water physisorption in spinel ferrites can be further enhanced by the obtained porous structure, where pores of different sizes, shape and connectivity can enhance water physisorption. As shown in SEM images of zinc ferrite thick film samples in Figure 1 and Figure 9, the analyzed $\mathrm{ZnFe}_{2} \mathrm{O}_{4}$ thick film samples had a porous structure consisting of agglomerated small nanocrystalline grains of $\mathrm{ZnFe}_{2} \mathrm{O}_{4}$ forming a porous network of aggregated nanoparticles.

This article is protected by copyright. All rights reserved. 
Analysis of $\mathrm{Hg}$ porosimetry measurements of the starting $\mathrm{ZnFe}_{2} \mathrm{O}_{4}$ powder and $\mathrm{ZnFe}_{2} \mathrm{O}_{4}$ powder obtained by peeling the thick film off the sensor substrate showed that there was a slight increase in porosity in the thick film compared to the starting powder and even though there was a slight decrease in porosity after two runs (1-2) the porosity values at about $60 \%$ remained relatively high.The microstructure and porosity can further be improved by optimizing the powder synthesis process, thick film composition and sintering temperature and this will be the subject of further work.

\subsection{Complex impedance analysis}

Complex impedance plots obtained for $\mathrm{ZnFe}_{2} \mathrm{O}_{4}$ thick film samples are shown in Figure 9. With increase in relative humidity the impedance decreased, starting with part of a depressed semicircular arc at lower humidity, ending with a depressed semicircle at high humidity values. Similar values were obtained for both analyzed operating temperatures, 25 (Figure 10a) and $50^{\circ} \mathrm{C}$ (Figure 10b). Impedance data was analyzed with the EIS Spectrum Analyzer Software ${ }^{46}$ using an equivalent circuit consisting of a parallel resistance and constant phase element (CPE) representing the dominant grain boundary influence. The CPE element was used to replace a capacitor in order to compensate for the depressed semicircle as described in detail in ${ }^{47}$. Good agreement between measured and analyzed spectra was obtained as shown in the example presented on insets in Figure 10, with an average error of about $2 \%$.

The determined grain boundary resistance was high for low $\mathrm{RH}$ and decreased rapidly with the increase in $\mathrm{RH}$ as shown in Figure 11 left (starting with $\mathrm{RH}$ of $50 \%$ as for lower $\mathrm{RH}$ the determined grain boundary resistance was above $1 \mathrm{G} \Omega$ and could not be precisely determined using the applied EIS Spectrum Analyzer Software). The determined grain boundary relaxation frequency increased with increase in RH (Figure 11 right). The determined grain boundary capacitance

This article is protected by copyright. All rights reserved. 
maintained a relatively similar value with change in $\mathrm{RH}$ and was in the range $101-115 \mathrm{pF}$ for both analyzed operating temperatures $\left(25\right.$ and $\left.50^{\circ} \mathrm{C}\right)$.

\section{CONCLUSION}

In this work we have analyzed the change of impedance of $\mathrm{ZnFe}_{2} \mathrm{O}_{4}$ thick films in a humidity chamber in the relative humidity range $30-90 \%$ at two operating temperatures - room temperature $\left(25^{\circ} \mathrm{C}\right)$ and a slightly increased temperature of $50^{\circ} \mathrm{C}$. The measured impedance decreased with increase in humidity and also frequency showing the most noticeable change of $\sim 46$ times at $42 \mathrm{~Hz}$, indicating that there is potential for application as humidity sensors. $\mathrm{ZnFe}_{2} \mathrm{O}_{4}$ powder with small amounts of residual unreacted zinc-oxide and hematite was obtained by solid state synthesis. The nanocrystalline mixed spinel structure of the obtained powder was confirmed using XRD, XPS, Raman spectroscopy, FESEM and TEM analysis. Thick films with a porous nanocrystalline structure (confirmed by SEM and Hg porosimetry analysis) were obtained by screen printing thick film paste on alumina substrates with test interdigitated PdAg electrodes. The measured complex impedance was analyzed using an equivalent circuit confirming the dominant influence of grain boundaries.

\section{ACKNOWLEDGEMENTS}

The authors would like to express their gratitude to Dr. M. Mitrić for XRD measurements and

Dr. Obrad Aleksic for useful discussions. This work was performed as part of projects III45007 and III45014 financed by the Ministry for Education, Science and Technological Development of the Republic of Serbia.

This article is protected by copyright. All rights reserved. 


\section{REFERENCES}

1. Sutka A. Gross K. A. Spinel ferrite semiconductor gas sensors. Sensors Actuators B 2016; 222:95-105.

2. Xu X. Xiao L. Haugen N. O. Wu Z. Jia Y. Zhong W. Zou J. High humidity response property of sol-gel synthesized $\mathrm{ZnFe}_{2} \mathrm{O}_{4}$ films. Materials Letters 2016; 213:266-268.

3. Lipare A. Y. Vasambekar P. N. Vaingankar A. S. Dielectric behavior and a.c. resistivity study of humidity sensing ferrites. Mat. Chem. Phys. 2003; 81:108-115.

4. Patil S. N. Pawar A. M. Tilekar S. K. Ladgaonkar B. P. Investigation of magnesium substituted nano particle zinc ferrites for relative humidity sensors. Sens Actuators A 2016; 244:35-43.

5. Shrivastava R. Yadav B. C. Nanostructured $\mathrm{ZnFe}_{2} \mathrm{O}_{4}$ thick film as room temperature liquefied petroleum gas sensor. Journal of Experimental Nanoscience 2015; 10:703-717.

6. Kamble R. B. Mathe V. L. Nanocrystalline nickel ferrite thick film as an efficient gas sensor at room temperature. Sensors Actuators B 2008; 131:205-209.

7. Virlan C. Tudorache F. Pui A. Increased sensibility of mixed ferrite humidity sensors by subsequent heat treatment. Int J Appl Ceram Technol 2017; 14:1174-1182.

8. Tudorache F. Investigations on microstructure, electrical and magnetic properties of copper spinel ferrite with $\mathrm{WO}_{3}$ addition for applications in the humidity sensors. Superlattices and Microstructures 2018; 116:131-140

9. Lazarevic Z. Z. Jovalekic C. Milutinovic A. Sekulic D. Recnik A. Cekic B. Romcevic N. Z. Nanodimensional spinel $\mathrm{NiFe}_{2} \mathrm{O}_{4}$ and $\mathrm{ZnFe}_{2} \mathrm{O}_{4}$ ferrites prepared by soft mechanochemical synthesis. J Appl Phys 2013; 113:187221.

10. Qin M. Shuai Q. Wu G. Zheng B. Wang Z. Wu H. Zinc ferrite composite material with controllable morphology and its applications. Mat Sci Eng B 2017; 224:125-138.

11. Pradeep A. Priyadharsini P. Chandrasekaran G. Structural, magnetic and electrical properties of nanocrystalline zinc ferrite. J Alloys Compd 2011; 509:3917-3923.

This article is protected by copyright. All rights reserved. 
12. Yadav R. S. Kuritka I. Vilcakova J. Urbinek P. Machovsky M. Masar M. Holek M. Structural, magnetic, optical, dielectric, electrical and modulus spectroscopic characteristics of $\mathrm{ZnFe}_{2} \mathrm{O}_{4}$ spinel ferrite nanoparticles synthesized via honey-mediated sol-gel combustion method. J Phys Chem Solids 2017; 110:87-99.

13. Sharma R. K. Ghose R. Synthesis and characterization of nanocrystalline zinc ferrite spinel powders by homogenous precipitation method. Ceram Int 2015; 41:14684-14691.

14. Dhiman M. Sharma R. Kumar V. Singhal S. Morphology controlled hydrothermal synthesis and photocatalytic properties of $\mathrm{ZnFe}_{2} \mathrm{O}_{4}$ nanostructures. Ceram Int 2016; 42:12594-12605.

15. Yadav R. S. Havlica J. Masilko J. Tkacz J. Kuritka I. Vilcakova J. Anneal-tuned structural, dielectric and electrical properties of $\mathrm{ZnFe}_{2} \mathrm{O}_{4}$ nanoparticles synthesized by starch-assisted sol-gel auto-combustion method. J Mater Sci:Mater Electron 2016; 27:5992-6002.

16. Liu T. Liu J. Liu Q. Rumin L. Zhang H. Jing X. Shape-controlled fabrication and enhanced gas sensing properties of uniform sphere-like $\mathrm{ZnFe}_{2} \mathrm{O}_{4}$ hierarchical architectures. Sensors Actuators B 2017; 250:111-120.

17. Li L. Tan J. Dun M. Huang X. Porous $\mathrm{ZnFe}_{2} \mathrm{O}_{4}$ nanorods with net-worked nanostructure for highly sensor response and fast response acetone gas sensor. Sensors Actuators B 2017; 248:85-91.

18. Liu Q. Cao F. Wu F. Tian W. Li L. Interface reacted $\mathrm{ZnFe}_{2} \mathrm{O}_{4}$ on $\alpha-\mathrm{Fe}_{2} \mathrm{O}_{3}$ nanoarrays for largely improved photoelectrochemical activity. RSC Advances 2015; 5:79440-79446.

19. Wang S. Gao X. Yang J. Zhu Z. Zhang H. Wang Y. Synthesis and gas sensor application of $\mathrm{ZnFe}_{2} \mathrm{O}_{4}-\mathrm{ZnO}$ composite hollow microspheres, RSC Advances 2014; 4:57967-57974

20. Li W. Wu X. Chen J. Gong Y. Han N. Chen Y. Abnormal n-p-n type conductivity transition of hollow $\mathrm{ZnO} / \mathrm{ZnFe}_{2} \mathrm{O}_{4}$ nanostructures during gas sensing process The role of $\mathrm{ZnO}-\mathrm{ZnFe}_{2} \mathrm{O}_{4}$ hetero-interface. Sens. Actuators B 2017; 253:144-155.

This article is protected by copyright. All rights reserved. 
21. Wang S. Zhang J. Yang J. Gao X. Zhang H. Wang Y. Zhu Z. Spinel $\mathrm{ZnFe}_{2} \mathrm{O}_{4}$ nanoparticledecorated rod-like $\mathrm{ZnO}$ nanoheterostructures for enhanced gas sensing performances. RSC Advances 2015; 5:10048-10057.

22. Ito S. Chen P. Comte P. Nazeeruddin M. K. Liska P. Pechy P. Gratzel M. Fabrication of ScreenPrinting Pastes From $\mathrm{TiO}_{2}$ Powders for Dye-Sensitised Solar Cells. Progress Photovoltaics 2007; 15:603-612.

23. Nazeeruddin M. K. Péchy P. Renourd T. Zakeeruddin S.M. Humphry-Baker R. Compte P. Engineering of efficient panchromatic sensitizers for nanocrystalline $\mathrm{TiO}_{2}$-based solar cells. J. Am. Chem. Soc. 2001; 123:1613-1624.

24. Toby B. H. Von Dreele R. B. GSAS-II the genesis of a modern open-source all purpose crystallography software package. J Appl Cryst 2013; 46:544-549.

25. Waerenborgh J. C. Figueredo M. O. Cabral J. M. P. Perreira L. C. J. Temperature and composition dependence of the cation distribution in synthetic $\mathrm{ZnFe}_{y} \mathrm{Al}_{2-y} \mathrm{O}_{4}(0 \leq y \leq 1)$ spinels. J Solid State Chem 1999; 111:300-309.

26. Shenoy S.D. Joy P.A. Anantharaman M.R. Effect of milling on the structural, magnetic and dielectric properties of coprecipitated ultrafine zinc ferrite. J. Magn. Magn. Mater. 2009 269:217-226

27. Lemine O.M. Bououdina M. Sajieddine M. Al-Saie A. M. Shafi M. Khatan A. Al-hilali M. Heninin M. Synthesis, structural, magnetic and optical properties of nanocrystalline $\mathrm{ZnFe}_{2} \mathrm{O}_{4}$. Physica B 2011; 406:1989-1994.

28. Sutka A. Parna R. Zamovskis M. Kisand V. Mezinkis G. Kleperis J. Maiorov M. Jakovlev D. Effect of antisite defects on the magnetic properties of $\mathrm{ZnFe}_{2} \mathrm{O}_{4}$, Phys Status Solidi A 2013; 210:1892-1897.

29. Druska P. Steinike U. Surface structure of mechanically activated and of mechanosynthesized zinc ferrite. J Solid State Chem 1999; 146:13-21.

This article is protected by copyright. All rights reserved. 
30. Bera S. Prince A. A. M. Velmurugan S. Raghavan P. S. Gopalan R. G. Panneerselvam, Narasimhan S. V. Formation of zinc ferrite by solid-state reaction and its characterization by XRD and XPS. J Mater Sci 2001; 36:5379-5384.

31. Marco J. F. Gancedo J. R. Gracia M. M Gautier J. L. Rios E. Berry F. J. Characterization of the nickel cobaltite $\mathrm{NiCO}_{2} \mathrm{O}_{4}$ prepared by several methods: an XRD, XANES, EXAFS and XPS study. J Solid State Chem 2000; 153:74-81.

32. Tavares A. C. da Silva Pereira M. I. Mendon M. H. Nunes M. R. Costa F. M. Sa C. M. XPS and voltammetric studies on $\mathrm{Ni}_{1-x} \mathrm{Cu}_{x} \mathrm{Co}_{2} \mathrm{O}_{4}$ spinel oxide electrodes. J Electroanal Chem 1998; 449:91-100.

33. Fan Z. Guo H. Fang K. Sun Y. Efficient $\mathrm{V}_{2} \mathrm{O}_{5} / \mathrm{TiO}_{2}$ composite catalysys for dimethioxymethane synthesis from methanol selective oxidation. RSC Adv 2015; 5:24795-24802.

34. Nappini S. Magnano E. Bondino F. Pis I. Barla A. Fantechi E. Pineider F. Sangregorio C. Vaccari L. Venturelli L. Baglioni P. Surface charge and coating of $\mathrm{CoFe}_{2} \mathrm{O}_{4}$ nanoparticles: evidence of preserved magnetic and electronic properties. J Phys Chem C 2015; 119:25529-25541.

35. Singh J. P. Srivastava R. C. Agrawal H. M. Kumar R. Micro-Raman investigation of nanosized zinc-ferrite: effect of crystallite size and influence of irradiation. J Raman Spectroscopy 2011; 42:1510-1517.

36. Rivero M. del Campo A. Mayoral A. Mazario E. Sanchez-Marcos J. Munoz-Bonilla A. Synthesis and structural characterization of $\mathrm{Zn}_{x} \mathrm{Fe}_{3-\mathrm{x}} \mathrm{O}_{4}$ ferrite nanoparticles obtained by an electrochemical method. RSC Adv 2016; 6:40067-40076.

37. Peeters D. Taffa D. H. Kerrigan M. M. Ney A. Jöns N. Rogalla D. Cwik S. Becker H.W. Grafen M. Ostendorf A. Winter C. H. Chakraborty S. Wark M. Devi A. Photoactive zinc-ferrites fabricated via conventional CVD approach. ACS Sustainable Chem Eng 2017; 5:2917-2926.

38. Wang Z. Schiferl D. Zhao Y. O’Neill H. St. C. High pressure Raman spectroscopy of spinel-type ferrite $\mathrm{ZnFe}_{2} \mathrm{O}_{4}$. J Phys Chem Solids 2003; 64:2517-2523.

This article is protected by copyright. All rights reserved. 
39. Lazarević Z. Ž. Jovalekić Č. Ivanovski V. N. Rečnik A. Milutinović A. Cekić B. Romčević N. Ž. Characterization of partially inverse spinel $\mathrm{ZnFe}_{2} \mathrm{O}_{4}$ with high saturation magnetization synthesized via soft mechanochemically assisted route. J Phys Chem Solids 2014; 75:869877.

40. Lowell S. Shields J.E. Thomas M.A. Characterization of Porous Solids and Powders: Surface Area, Pore Size and Density (Particle Technology Series), Matthias Thommes Kluwer Academic Publishers, Dordrecht, 2004.

41. Finčur N. L. Krstić J. B. Šibul F. S. Šojić D. V. Despotović V. N. Banić N. D. Agbaba J. R. Abramović B. F. Removal of alprazolam from aqueous solutions by heterogeneous photocatalysis: Influencing factors, intermediates, and products. Chemical Engineering Journal 2017; 3071105-1115.

42. Emeruwa E. Jarrige J Mexmain J. Bernardin M. Application of mercury porosimetry to powder $\left(\mathrm{UO}_{2}\right)$ analysis. J. Nuclear Mater 1991; 184:53-58

43. Mirzaei A. Hashemi B. Janghorban K. $\alpha-\mathrm{Fe}_{2} \mathrm{O}_{3}$ based nanomaterials as gas sensors. J Mater Sci: Mater Electron 2016; 27:3109-3144.

44. Agmon N. The Grotthuss mechanism. Chem Phys Lett 1995; 244:456-462.

45. Erol A. Okur S. Comba B. Mermer O. Arikan M. C. Humidity sensing properties of ZnO nanoparticles synthesized by sol-gel process. Sens. Actuators B. 2010; 145:174-180.

46. Bondarenko A. S. Ragoisha G. EIS Spectrum Analyzer, http://www.abc.chemistry.bsu.by

47. Nikolic M. V. Sekulic D. L. Vasiljevic Z. Z. Lukovic M. D. Pavlovic V. B. Aleksic O. S. Dielectric properties, complex impedance and electrical conductivity of $\mathrm{Fe}_{2} \mathrm{TiO}_{5}$ nanopowder compacts and bulk samples at elevated temperatures. J Mater Sci:Mater Electron 2017; 28 (2017) 4796-4806.

This article is protected by copyright. All rights reserved. 
FIGURE CAPTIONS

FIGURE 1 Fabricated $\mathrm{ZnFe}_{2} \mathrm{O}_{4}$ thick film test sample on alumina substrate with interdigitated electrodes (electrode spacing $0.25 \mathrm{~mm}$ ) and SEM images of thick film sample surface

FIGURE 2 XRD pattern of zinc-ferrite powder; refined patterns of zinc ferrite powder and thick film using GSAS-II

FIGURE 3 FESEM and TEM images of obtained zinc-ferrite powder

FIGURE 4 XPS spectra of $\mathrm{ZnFe}_{2} \mathrm{O}_{4}$ powder (a), deconvoluted $\mathrm{Zn2p}(\mathrm{b}), \mathrm{O} 1 \mathrm{~s}$ (c) and Fe (d) spectra FIGURE 5 Raman spectra of $\mathrm{ZnFe}_{2} \mathrm{O}_{4}$ powder using 0.4and $1 \mathrm{~W}$ He-Ne laser power

FIGURE $6 \mathrm{Hg}$ porosimetry measurements of the $\mathrm{ZnFe}_{2} \mathrm{O}_{4}$ powder (left) and $\mathrm{ZnFe}_{2} \mathrm{O}_{4}$ thick film peeled off the sensor substrate (right)

FIGURE 7 Change of impedance of $\mathrm{ZnFe}_{2} \mathrm{O}_{4}$ thick films with frequency at 25 and $50^{\circ} \mathrm{C}$ (inset) measured for relative humidity $30-90 \%$

This article is protected by copyright. All rights reserved. 
FIGURE 8 Change of impedance (left) and sensitivity (right) of $\mathrm{ZnFe}_{2} \mathrm{O}_{4}$ thick films with $\mathrm{RH}$, frequency $42 \mathrm{~Hz}$, at 25 and $50^{\circ} \mathrm{C}$

FIGURE 9 SEM image of thick film sample surface

FIGURE 10 Change of impedance with RH measured at $25(\mathrm{a})$ and $50^{\circ} \mathrm{C}(\mathrm{b})$, Insets: example of a fitted curve at $\mathrm{RH} 70$ (a) and $80 \%$ (b), respectively

FIGURE 11 Change of grain boundary resistance (left) and grain boundary relaxation frequency (right) with relative humidity

This article is protected by copyright. All rights reserved. 
TABLE 1 Structural parameters for $\mathrm{ZnFe}_{2} \mathrm{O}_{4}$ powder obtained by Rietveld refinement of XRD pattern, $w R=4.685 \%$ (values in brackets represent the calculation error for one or two decimals)

$\mathrm{ZnFe}_{2} \mathrm{O}_{4}(89.0$ wt.\%)

$F d \overline{3} m Z, a=8.42742(20) \AA$, Crystallite size: $46 \mathrm{~nm}$, Microstrain: $8.6(4) \cdot 10^{3}$

\begin{tabular}{|c|c|c|c|c|c|c|}
\hline Atom & Site & $x$ & $y$ & $z$ & $U_{\text {iso }}$ & Occupancy \\
\hline Zn1 & $8 a$ & 0.125 & 0.125 & 0.125 & 0.0523 & 0.6 \\
\hline Fe1 & $8 a$ & 0.125 & 0.125 & 0.125 & 0.0523 & 0.4 \\
\hline $\mathrm{Zn} 2$ & $16 d$ & 0.500 & 0.500 & 0.500 & 0.0751 & 0.2 \\
\hline Fe2 & $16 d$ & 0.500 & 0.500 & 0.500 & 0.0751 & 0.8 \\
\hline 0 & $32 e$ & $0.2596(5)$ & 0.2596 & 0.2596 & 0.0508 & 1 \\
\hline \multicolumn{2}{|c|}{ O-Zn1,Fe1 distance } & \multicolumn{5}{|l|}{$1.9642(26) \AA$} \\
\hline \multicolumn{2}{|c|}{ O-Zn2,Fe2 distance } & \multicolumn{5}{|c|}{$2.02943(18) \AA$} \\
\hline \multicolumn{7}{|c|}{ ZnO (9.8 wt.\%) } \\
\hline \multicolumn{7}{|c|}{$P 6_{3} m c, a=b=3.2437(6), c=5.1995(11) \AA$, Crystallite size: $44 \mathrm{~nm}$, Microstrain: $\left.9.6(22)\right) \cdot 10^{3}$} \\
\hline \multicolumn{7}{|c|}{$\mathrm{Fe}_{2} \mathrm{O}_{3}(1.2$ wt.\%) } \\
\hline \multicolumn{7}{|c|}{$R \overline{3} c, a=b=5.0677(11) ; c=13.6604(20) \AA$, Microstrain: $3.2(25)) \cdot 10^{3}$} \\
\hline
\end{tabular}

This article is protected by copyright. All rights reserved. 
TABLE II Parameters calculated from Hg porosimetry measurements

\begin{tabular}{|c|c|c|c|c|}
\hline & \multicolumn{2}{|c|}{$\mathrm{ZnFe}_{2} \mathrm{O}_{4}$} & \multicolumn{2}{|c|}{$\mathrm{tf}-\mathrm{ZnFe}{ }_{2} \mathrm{O}_{4}$} \\
\hline & Run1 & Run2 & Run1 & Run2 \\
\hline Total cumulative volume, $\left(\mathrm{cm}^{3} / \mathrm{g}\right)$ & 0.330 & 0.169 & 0.467 & 0.310 \\
\hline Specific surface area, $\left(\mathrm{m}^{2} / \mathrm{g}\right)$ & 6.8 & 4.9 & 7.6 & 5.7 \\
\hline Bulk density, $\left(\mathrm{g} / \mathrm{cm}^{3}\right)$ & 1.89 & 2.72 & 1.47 & 1.91 \\
\hline Apparent density, $\left(\mathrm{g} / \mathrm{cm}^{3}\right)$ & 5.06 & 5.06 & 4.66 & 4.66 \\
\hline Porosity, (\%) & 62.6 & 46.1 & 68.5 & 59.1 \\
\hline
\end{tabular}

This article is protected by copyright. All rights reserved. 


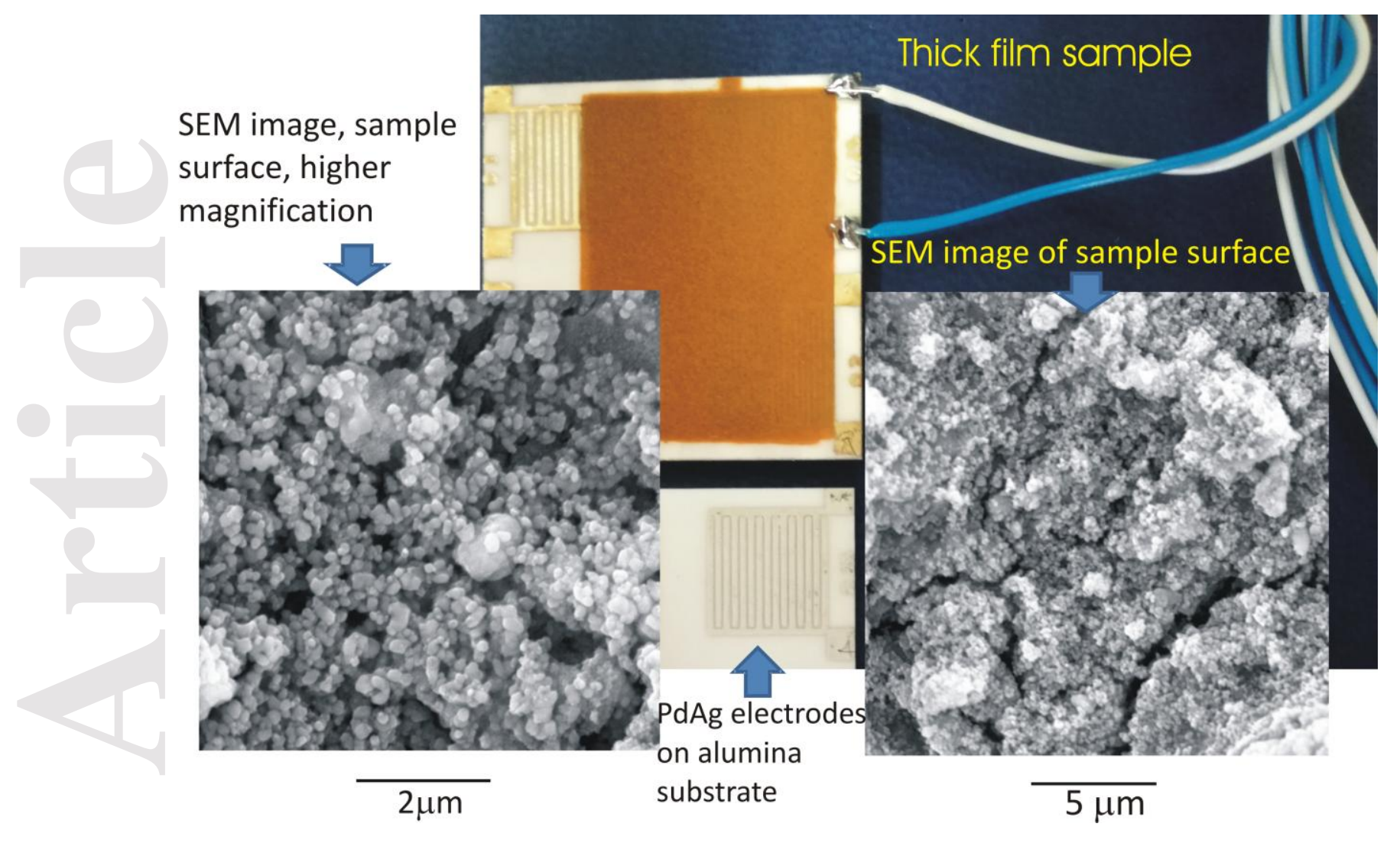

This article is protected by copyright. All rights reserved. 


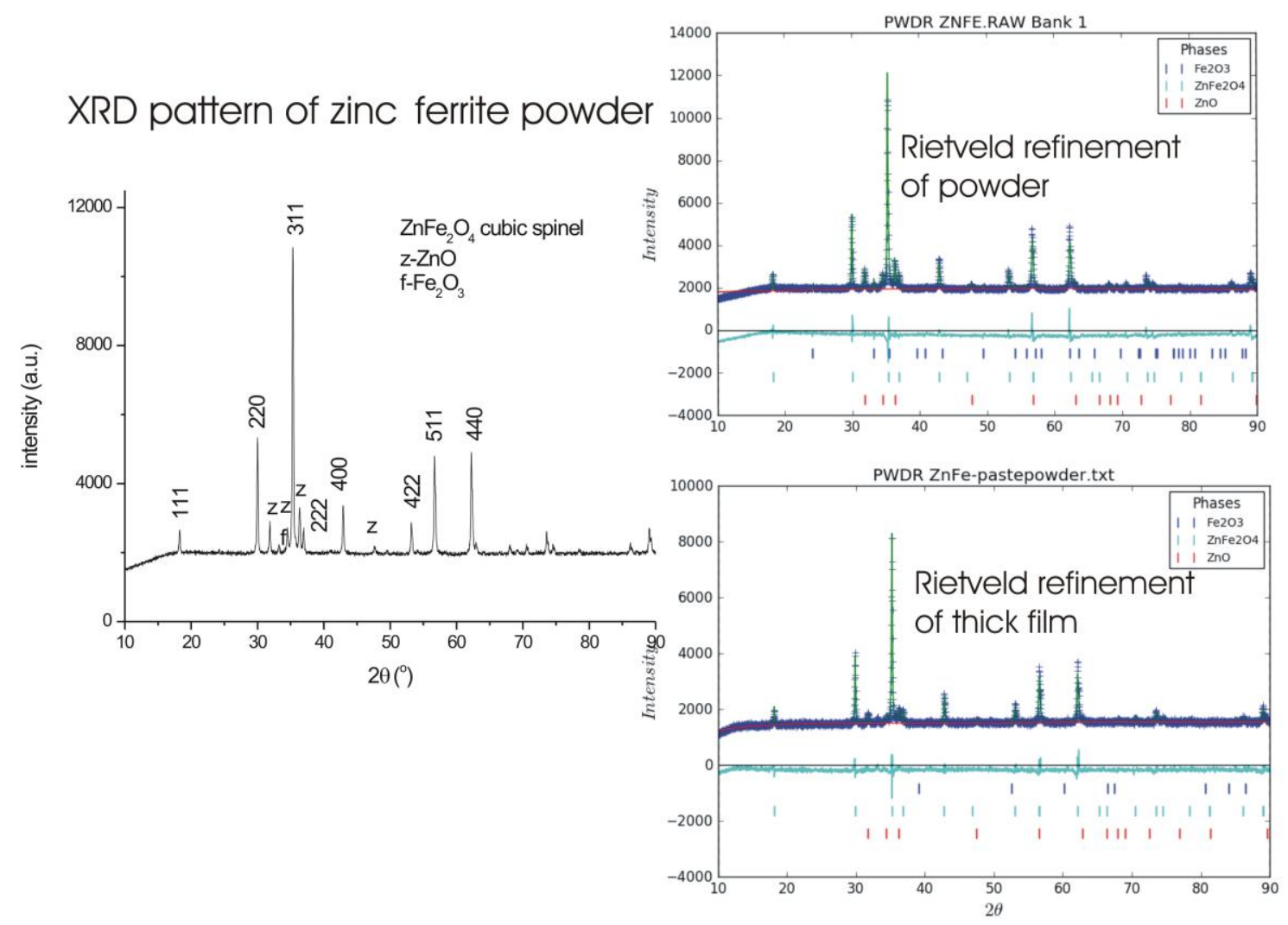

This article is protected by copyright. All rights reserved. 


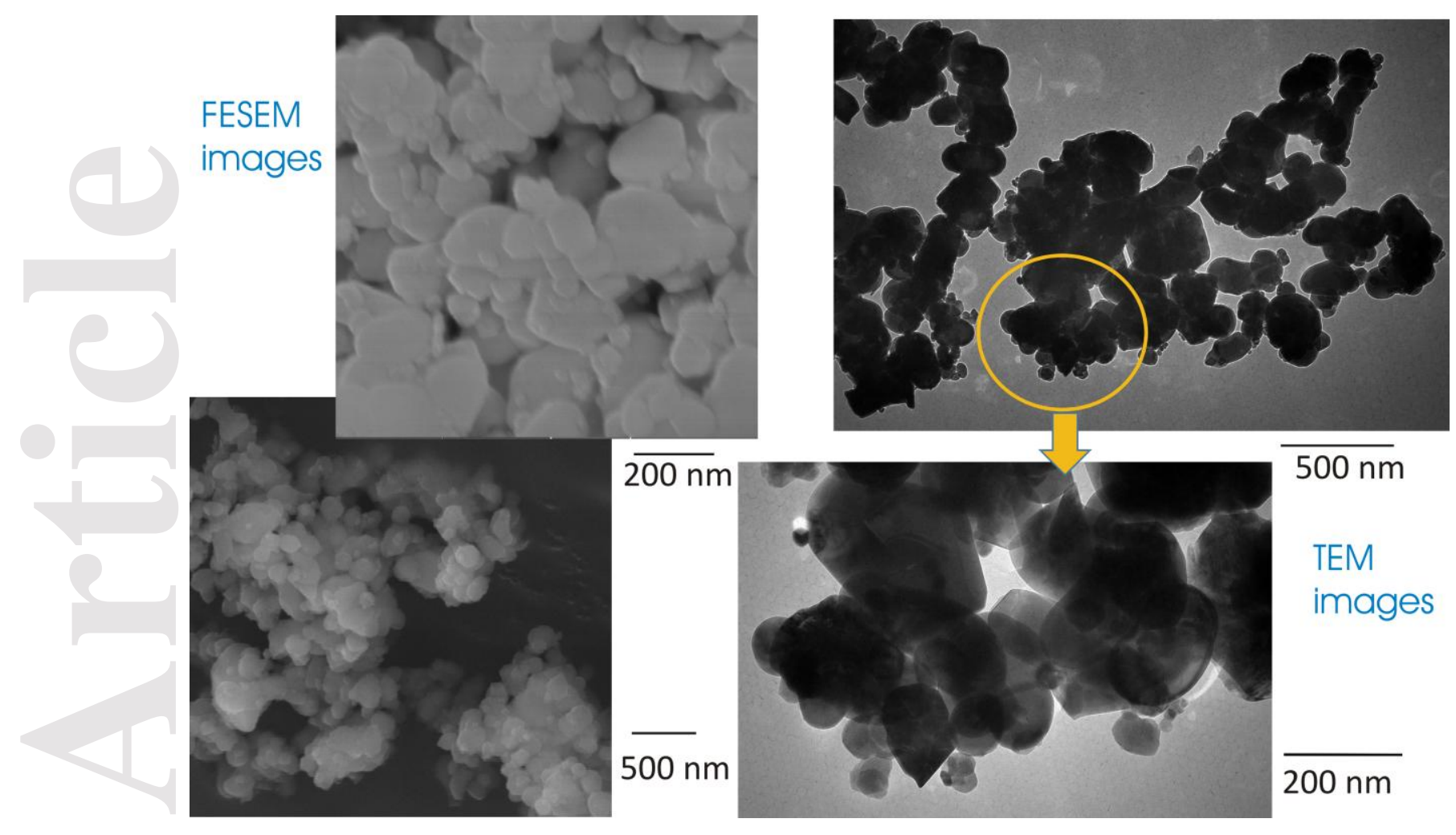

This article is protected by copyright. All rights reserved. 


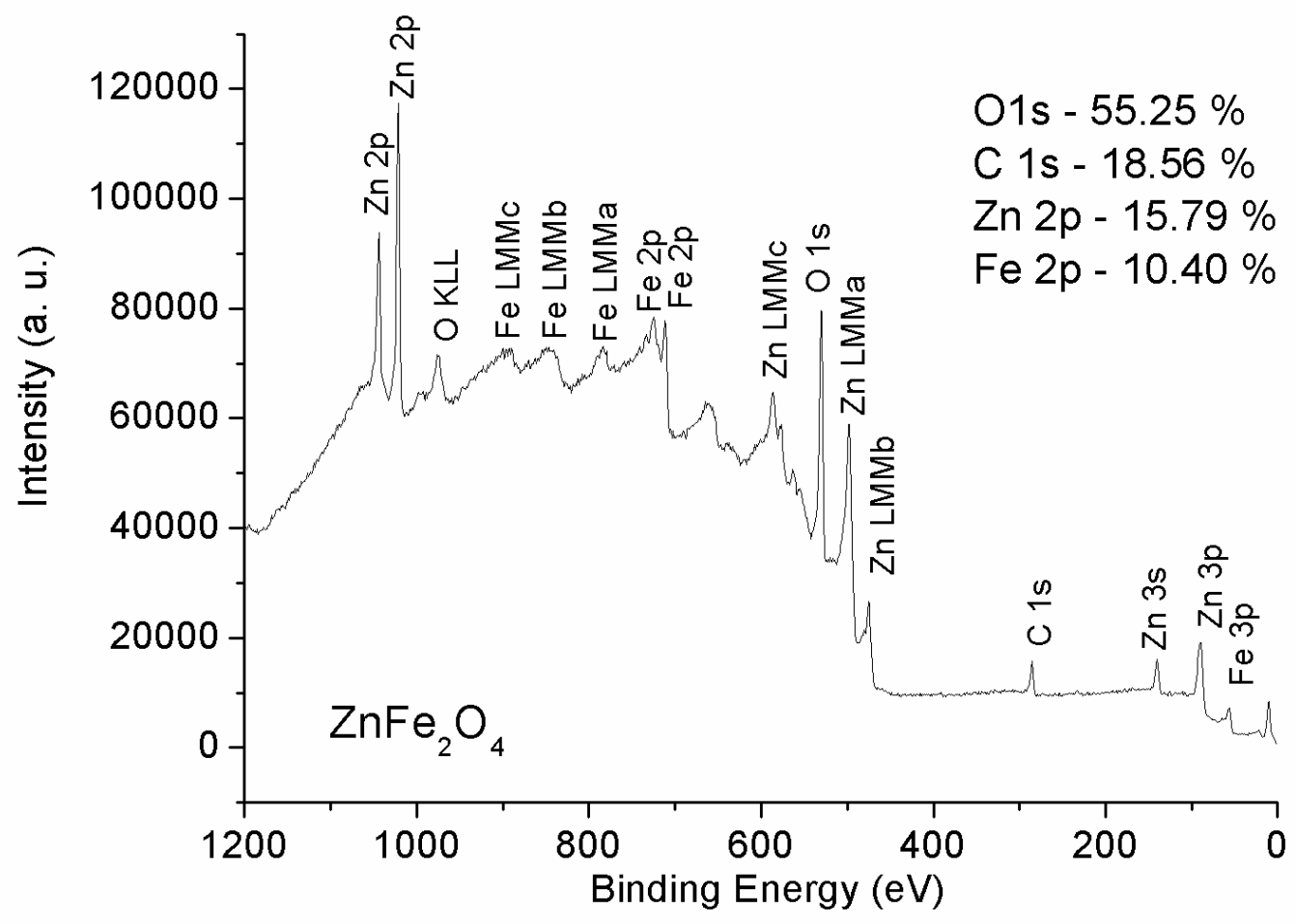

This article is protected by copyright. All rights reserved. 


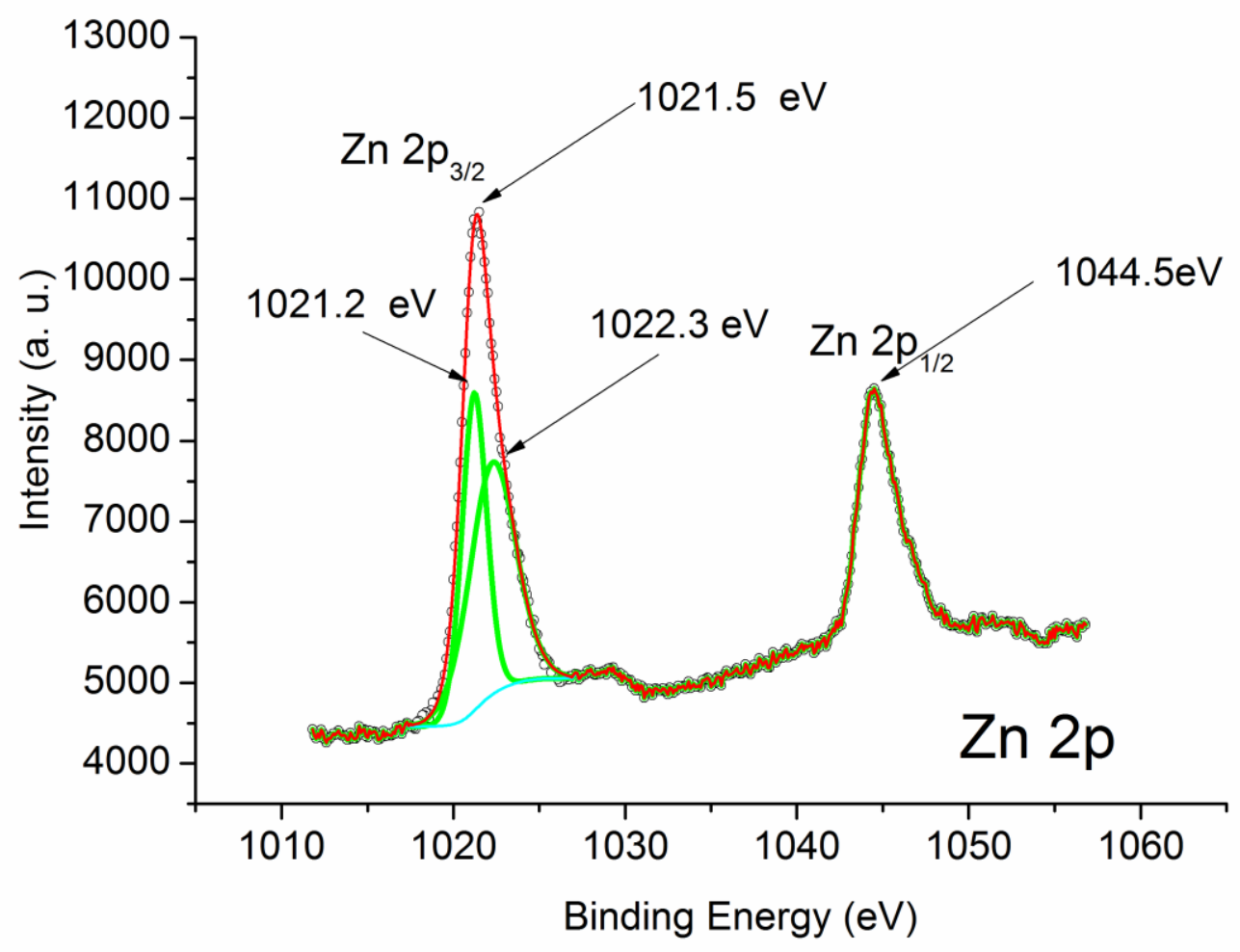

This article is protected by copyright. All rights reserved. 


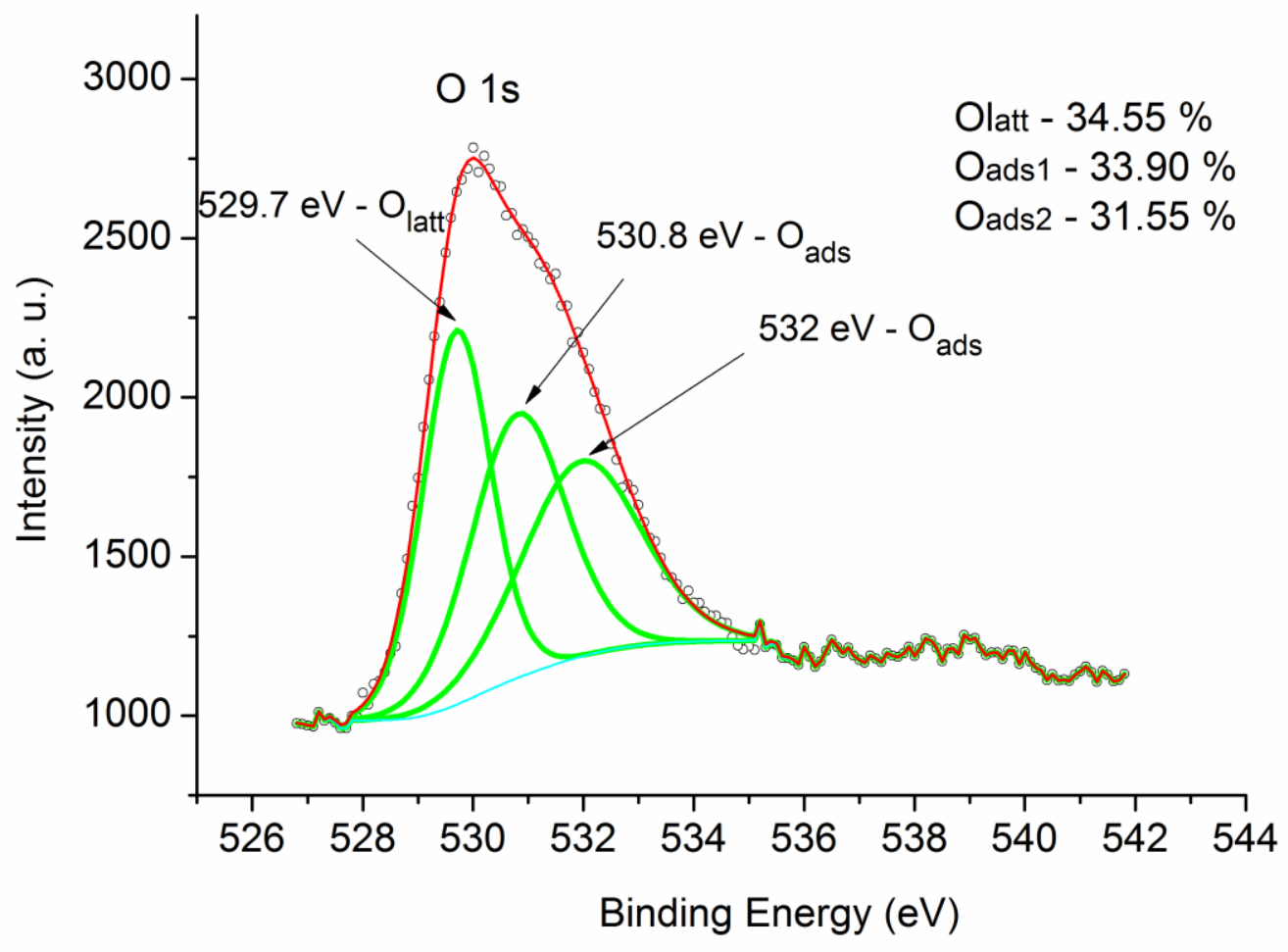

This article is protected by copyright. All rights reserved. 


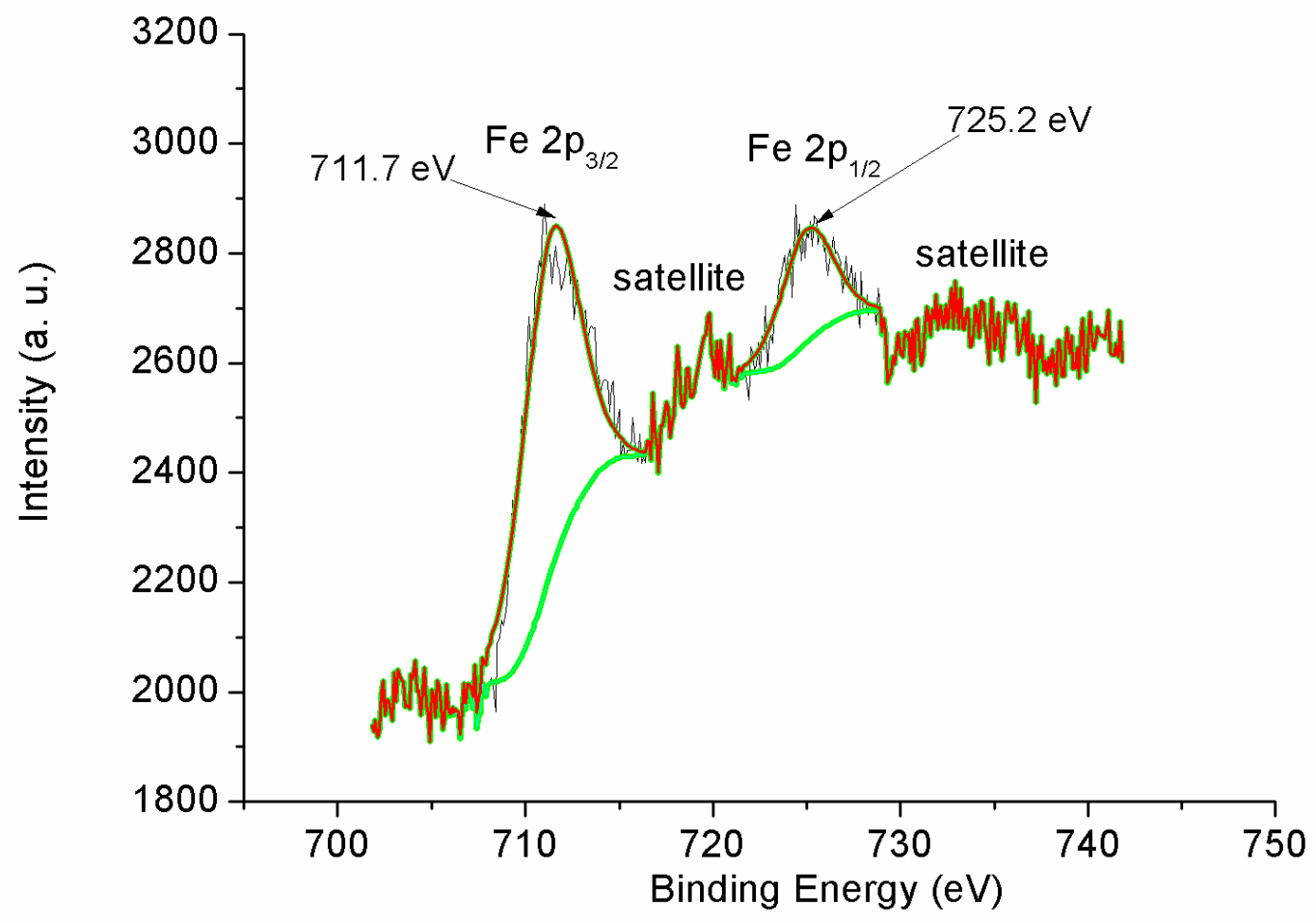

This article is protected by copyright. All rights reserved. 


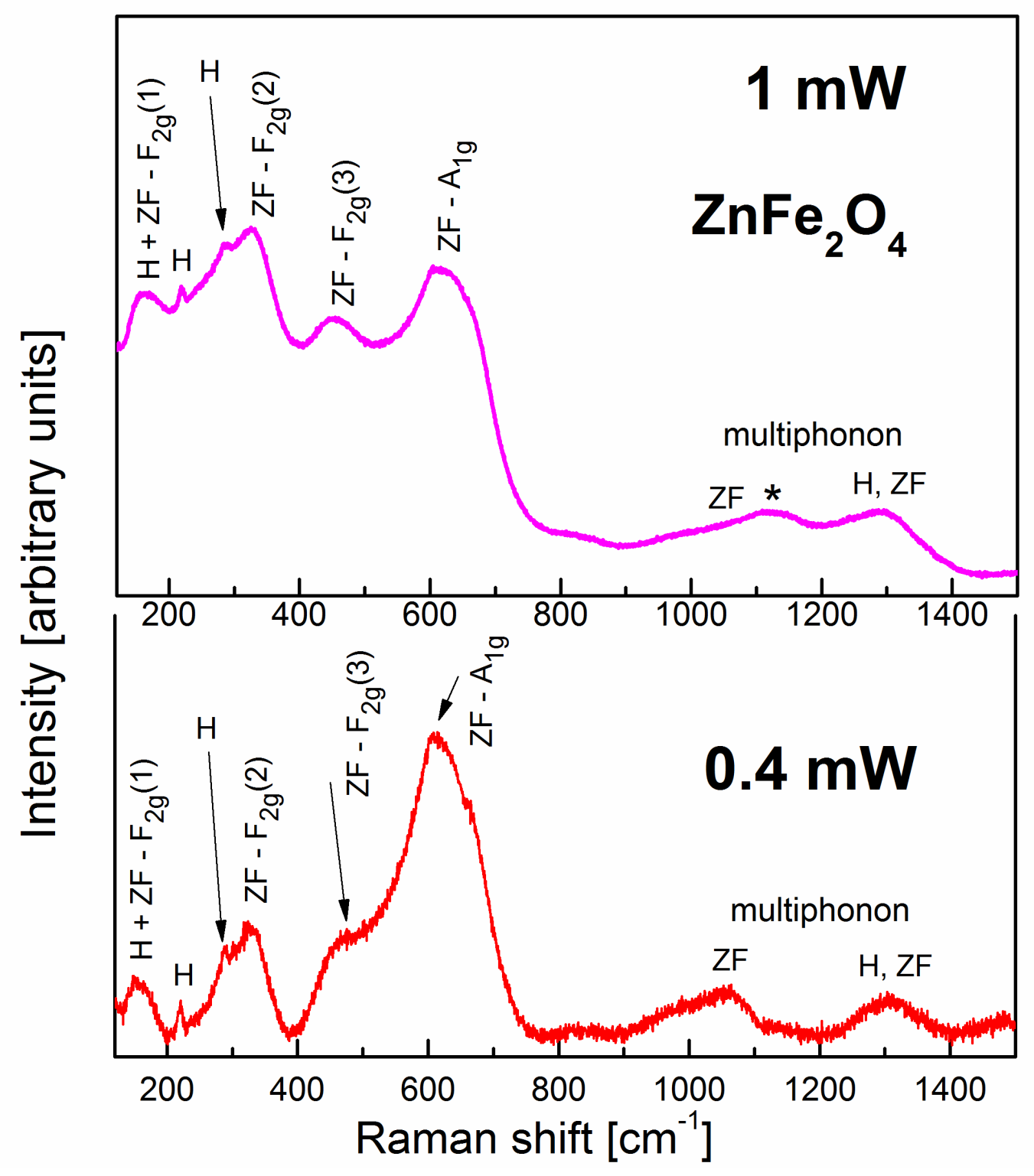

This article is protected by copyright. All rights reserved. 


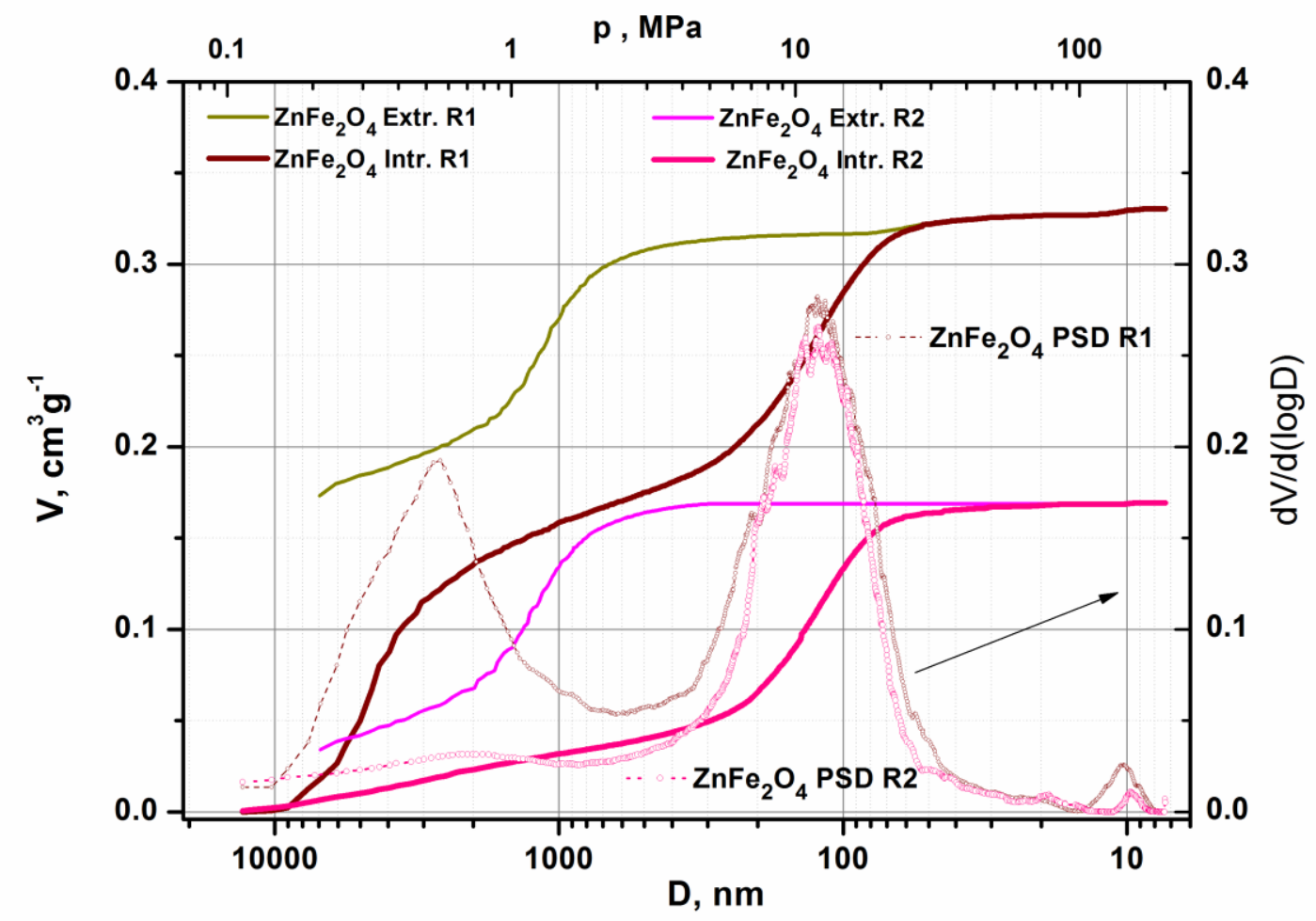

This article is protected by copyright. All rights reserved. 


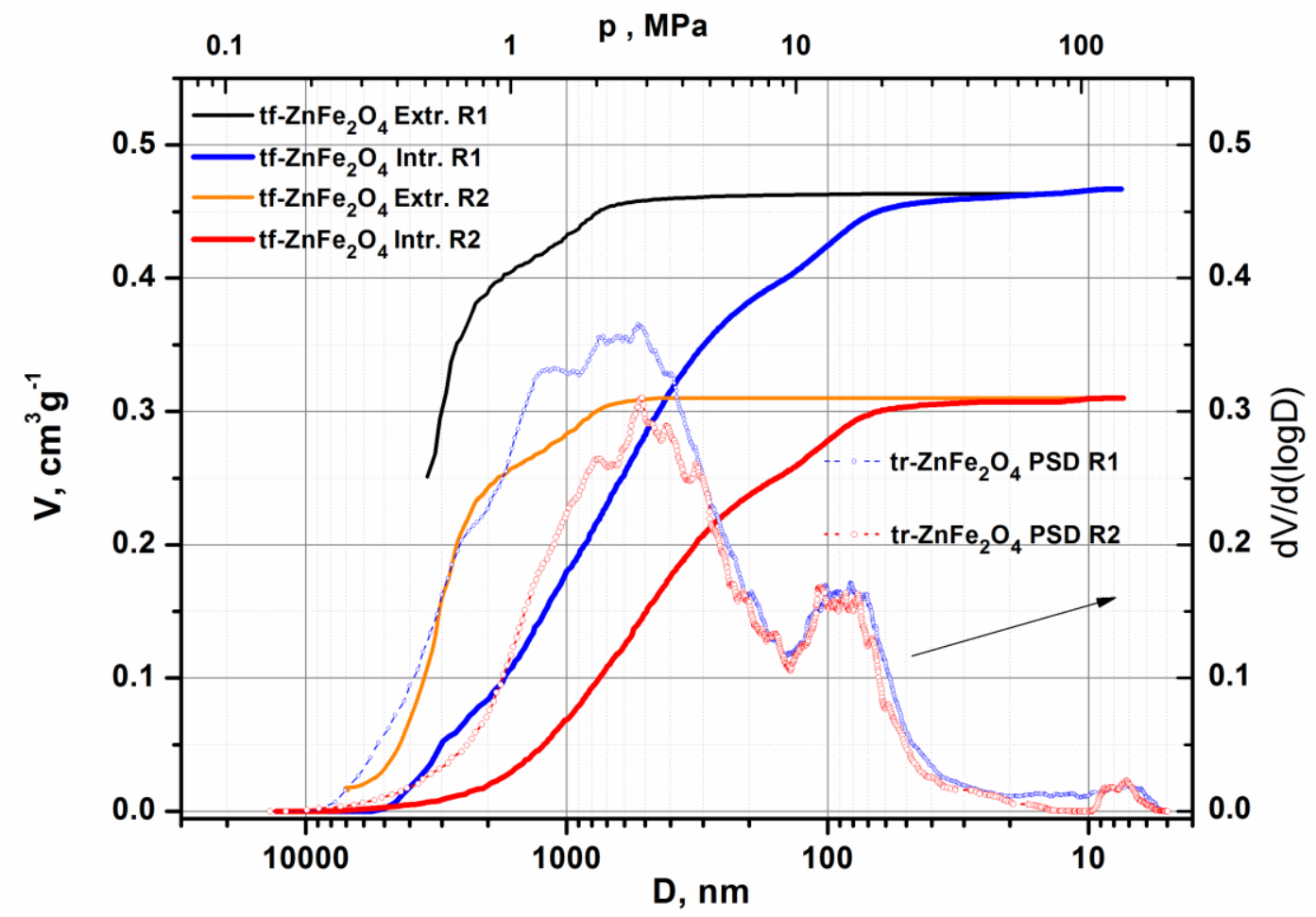

This article is protected by copyright. All rights reserved. 


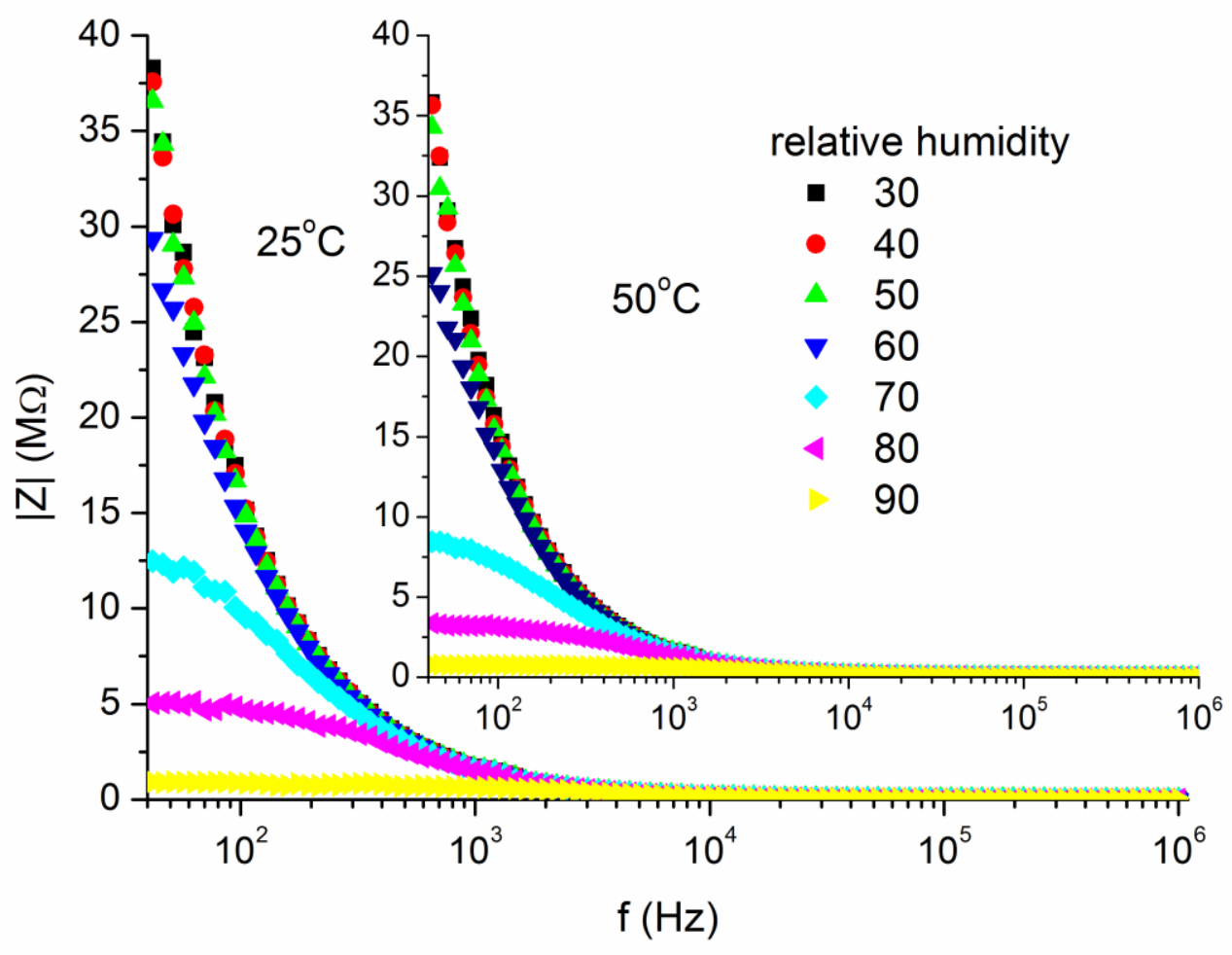

This article is protected by copyright. All rights reserved. 


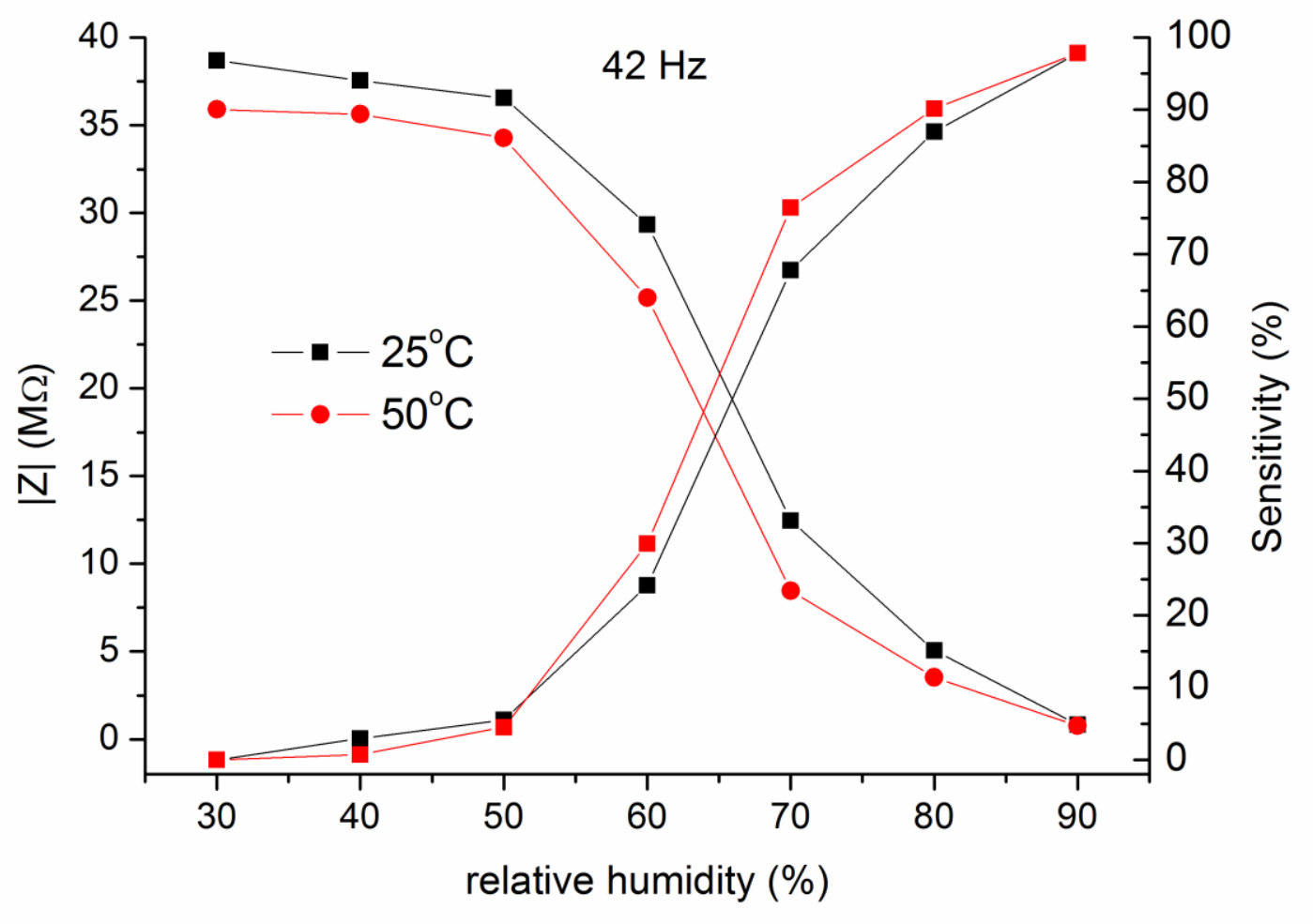

This article is protected by copyright. All rights reserved. 


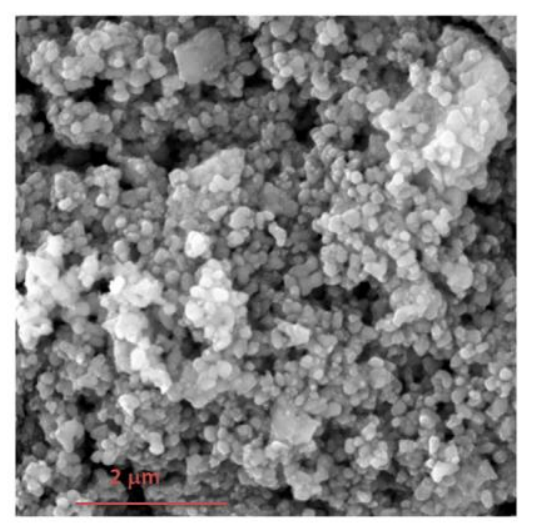

This article is protected by copyright. All rights reserved. 


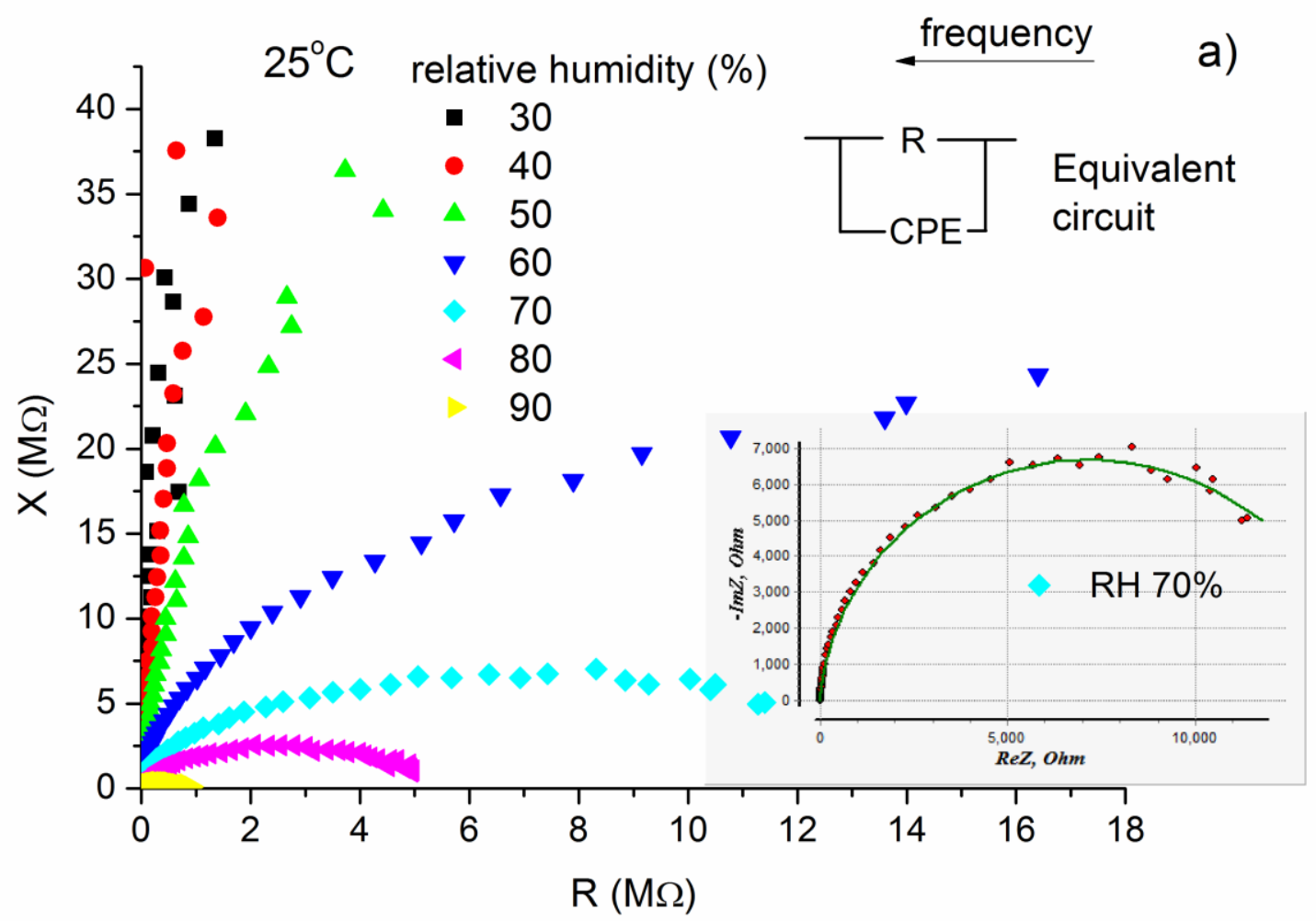

This article is protected by copyright. All rights reserved. 


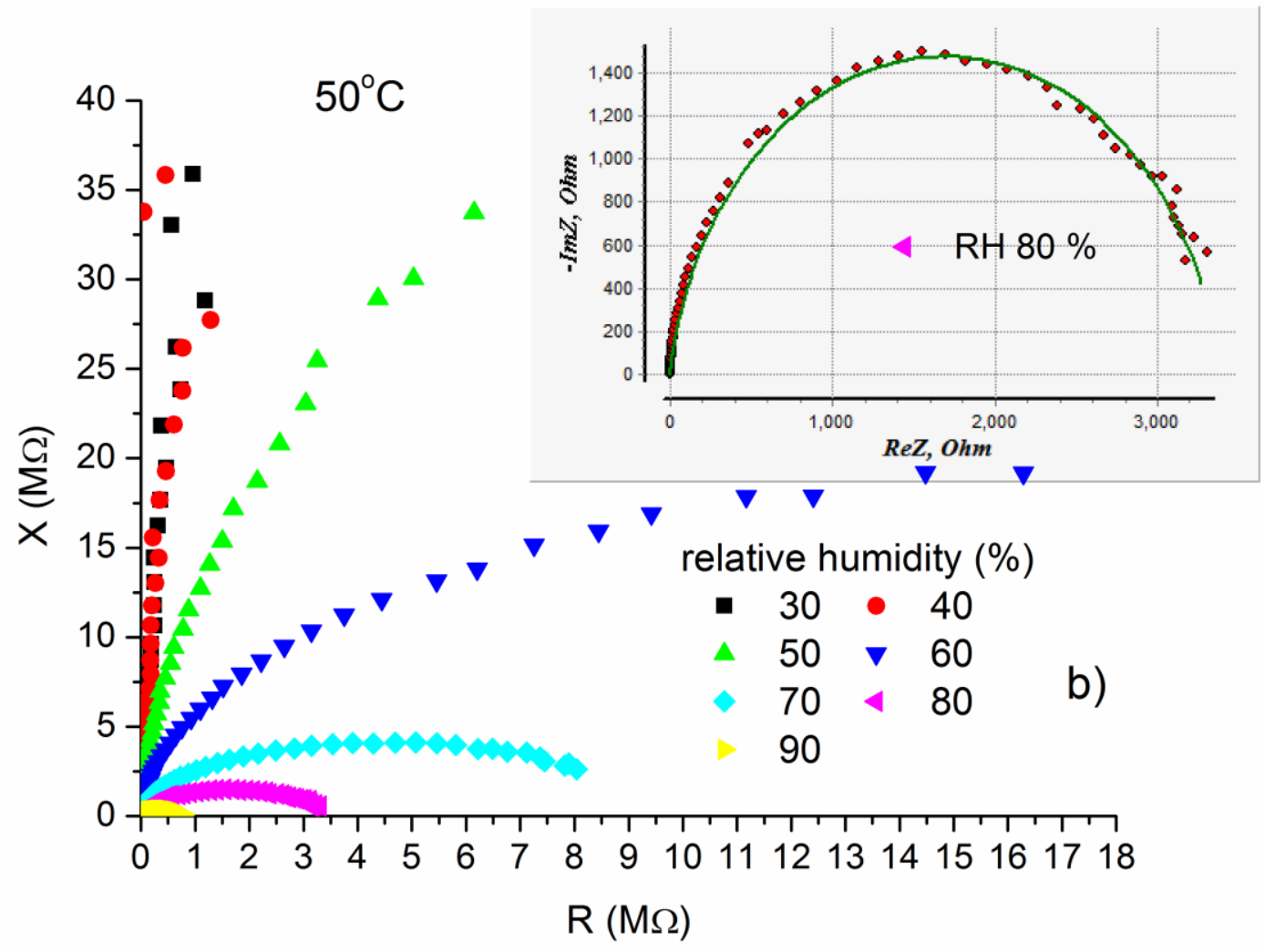

This article is protected by copyright. All rights reserved. 


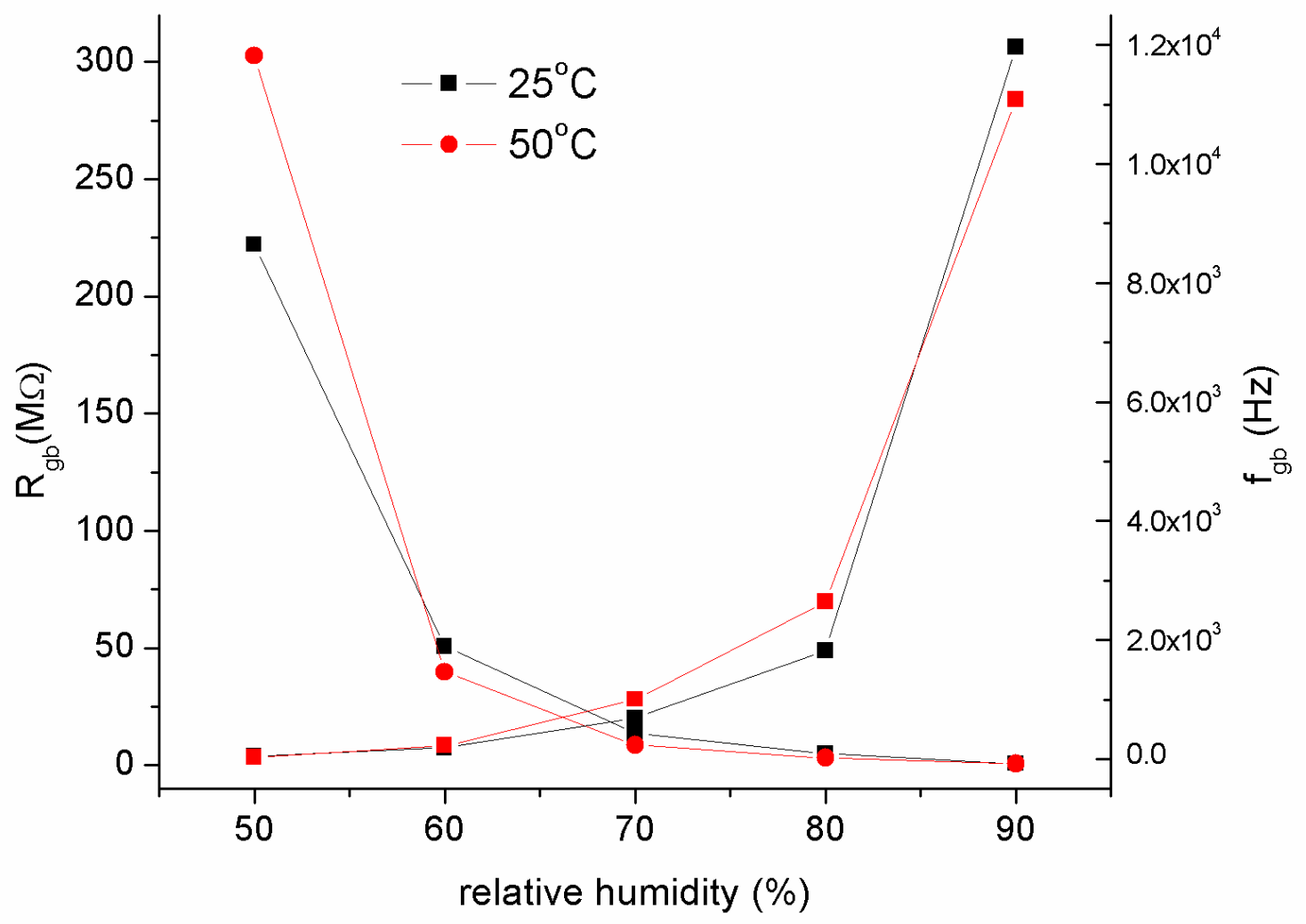

This article is protected by copyright. All rights reserved. 